Article

\title{
Interannual Climate Variability in the West Antarctic Peninsula under Austral Summer Conditions
}

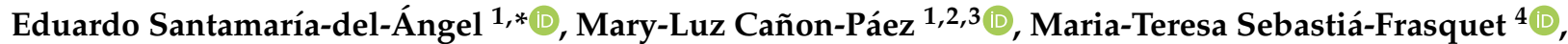 \\ Adriana González-Silvera ${ }^{1} \mathbb{D}$, Angelica-L. Gutierrez ${ }^{5}$, Jesús-A. Aguilar-Maldonado ${ }^{4} \mathbb{D}$, Jorge López-Calderón ${ }^{1}{ }^{\mathbb{D}}$, \\ Víctor Camacho-Ibar ${ }^{6}{ }^{\mathbb{D}}$, Andrés Franco-Herrera ${ }^{7}$ and Alejandra Castillo-Ramírez ${ }^{1,2}$
}

check for updates

Citation: Santamaría-del-Ángel, E.; Cañon-Páez, M.-L.; Sebastiá-Frasquet, M.-T.; González-Silvera, A.; Gutierrez, A.-L; Aguilar-Maldonado, J.-A;

López-Calderón, J.; Camacho-Ibar, V.; Franco-Herrera, A.; Castillo-Ramírez, A. Interannual Climate Variability in the West Antarctic Peninsula under Austral Summer Conditions. Remote Sens. 2021, 13, 1122.

https://doi.org/ 10.3390/rs13061122

Received: 28 December 2020

Accepted: 10 March 2021

Published: 16 March 2021

Publisher's Note: MDPI stays neutral with regard to jurisdictional claims in published maps and institutional affiliations.

Copyright: (C) 2021 by the authors Licensee MDPI, Basel, Switzerland. This article is an open access article distributed under the terms and conditions of the Creative Commons Attribution (CC BY) license (https:/ / creativecommons.org/licenses/by/ $4.0 /)$
1 Facultad de Ciencias Marinas, Universidad Autónoma de Baja California, Ensenada 22860, Baja California, Mexico; mary.canon@uabc.edu.mx (M.-L.C.-P.); adriana.gonzalez@uabc.edu.mx (A.G.-S.); jorge.lopez67@uabc.edu.mx (J.L.-C.); alejandra.castillo@uabc.edu.mx (A.C.-R.)

2 Programa de Doctorado en Oceanografía Costera, Facultad de Ciencias Marinas, Universidad Autónoma de Baja California, Ensenada 22860, Baja California, Mexico

3 Dirección General Marítima, Centro de Investigaciones Oceanográficas e Hidrográficas, Cartagena 13001, Colombia

4 Instituto de Investigación para la Gestión Integrada de Zonas Costeras, Universitat Politècnica de València, C/Paraninfo, 46730 Grau de Gandia, Spain; mtsebastia@hma.upv.es (M.-T.S.-F.); jeagmal@upv.es (J.-A.A.-M.)

5 Office of Water Prediction, National Oceanic and Atmospheric Administration (NOAA), Silver Spring, MD 20910, USA; angelica.gutierrez@noaa.gov

6 Instituto de Investigaciones Oceanológicas, Universidad Autónoma de Baja California, Ensenada 22860, Baja California, Mexico; vcamacho@uabc.edu.mx

7 Área Académica de Ciencias Biológicas y Ambientales, Universidad Jorge Tadeo Lozano, Bogotá 110311, Colombia; andres.franco@utadeo.edu.co

* Correspondence: santamaria@uabc.edu.mx

Abstract: This study aimed to describe the interannual climate variability in the West Antarctic Peninsula (WAP) under austral summer conditions. Time series of January sea-surface temperature (SST) at $1 \mathrm{~km}$ spatial resolution from satellite-based multi-sensor data from Moderate Resolution Imaging Spectrometer (MODIS) Terra, MODIS Aqua, and Visible Infrared Imager Radiometer Suite (VIIRS) were compiled between 2001 and 2020 at localities near the Gerlache Strait and the Carlini, Palmer, and Rothera research stations. The results revealed a well-marked spatial-temporal variability in SST at the WAP, with a one-year warm episode followed by a five-year cold episode. Warm waters (SST $>0{ }^{\circ} \mathrm{C}$ ) reach the coast during warm episodes but remain far from the shore during cold episodes. This behavior of warm waters may be related to the regional variability of the Antarctic Circumpolar Current, particularly when the South Polar Front (carrying warm waters) reaches the WAP coast. The WAP can be divided into two zones representing two distinct ecoregions: the northern zone (including the Carlini and Gerlache stations) corresponds to the South Shetland Islands ecoregion, and the southern zone (including the Palmer and Rothera stations) corresponds to the Antarctic Peninsula ecoregion. The Gerlache Strait is likely situated on the border between the two ecoregions but under a greater influence of the northern zone. Our data showed that the Southern Annular Mode (SAM) is the primary driver of SST variability, while the El Niño Southern Oscillation (ENSO) plays a secondary role. However, further studies are needed to better understand regional climate variability in the WAP and its relation with SAM and ENSO; such studies should use an index that adequately describes the ENSO in these latitudes and addresses the limitations of the databases used for this purpose. Multi-sensor data are useful in describing the complex climate variability resulting from the combination of local and regional processes that elicit different responses across the WAP. It is also essential to continue improving SST approximations at high latitudes.

Keywords: climate variability; West Antarctic Peninsula (WAP); SST; multi-sensor LAC imagery; fiveyear warm cycle; Southern Annular Mode (SAM)/Antarctic Oscillation (AAO); Southern Oscillation Index (SOI); WAP marine ecoregions; Group on Earth Observations (GEO) 


\section{Introduction}

The ozone hole over the Antarctic was first reported in the spring of 1985 [1]. This anomaly was one of the earliest global signals of how human activities can change the planetary climate. Since then, the Antarctic has played a key role in helping us understand global climate variability [2-4]. This issue has led some 30 countries to launch research programs on the continent, installing over 100 permanent facilities and 36 temporary field stations therein; the West Antarctic Peninsula (WAP) harbors 13 permanent and 24 temporary stations [5]. This region has become a human activity hotspot [6], given its accessibility with regular boats; vessels with icebreaker capabilities are necessary to gain access to other parts of the continent.

According to Saba et al. [7] and Kim et al. [8], the WAP is a climatically sensitive region that shows periods of intense warming. Such warming periods induce significant changes in the marine ecosystem, affecting every trophic level [9], particularly the structure of the phytoplankton community $[8,10,11]$, with repercussions for the energy flow in local trophic webs. Furthermore, the WAP is a transitional zone between a cold-dry and a warmer, humid subarctic climate [9]. For this reason, the WAP has been considered, since the late 20 th century, as one of the warmest regions of the continent $[6,10,12-15]$ in terms of sea-level air temperature [16,17], water temperature [10,15], and seabed temperature [18]. It has also become an area raising high scientific interest, with scientific publications describing the zone based on observations made either onboard oceanographic vessels or at the various research stations located therein. Most studies have described the austral summer, as the higher temperatures allow better working conditions [17]. A general conclusion of all those studies is that the WAP is a highly productive ecosystem strongly influenced by local physical variability $[7,8,19]$.

The Antarctic is a critical area for understanding climate variations worldwide [4]; thus, the data collected each austral summer should be compiled and examined to explain climate variability and describe its effects on local ecosystems [8,9]. This compilation is a challenging task since the climate and oceanographic conditions of a particular year may differ markedly from those in the following year, even at the same sampling locations.

Sea-surface temperature (SST) is a critical factor for describing ecosystem variability [20]. A long time series of SST data would be necessary to differentiate variability due to natural causes from fluctuations associated with anthropogenic processes [21]. However, data recorded in situ for the entire WAP are virtually impossible to obtain. For instance, Kim et al. [8] analyzed data from three stations, only two of which had quasi-continuous time series of in situ records of SST: the Palmer Long-Term Ecological Research (LTER) station [22] and the Rothera Time Series (RaTS) (part of the Polar Oceans programme of the British Antarctic Survey). For this reason, data from remote sensors such as spectroradiometers are a key source of information to compile a time series of sea-surface temperature, especially for areas with no in situ recorded information.

The objective of this study was to describe interannual climate variability in the WAP during the austral summer using SST multi-sensor data recorded by infrared sensors with a $1 \mathrm{~km}$ spatial resolution.

\section{Materials and Methods}

We selected January as a suitable representation of the austral summer. Multi-sensor January SST images for the period 2001-2020 were compiled to describe interannual climate variability in the WAP (Figure 1). Sensors included the Moderate Resolution Imaging Spectrometers (MODIS) onboard the Terra (since 2001) and Aqua (since 2003) satellites and the Suomi-NPP Visible Infrared Imager Radiometer Suite (VIIRS) (since 2012). The L1 data were obtained from [23], taking into account the quality-data flags set by reprocessing MODIST_R2019, MODISA_R2019, and VIIRS_v2016.1, respectively. These data were processed using standard SST algorithms with the SeaDAS 7.5 software package [24,25], resulting in 11-12 $\mu \mathrm{m}$ daytime SST images in local area coverage (LAC, $1 \mathrm{~km}$ resolution). 


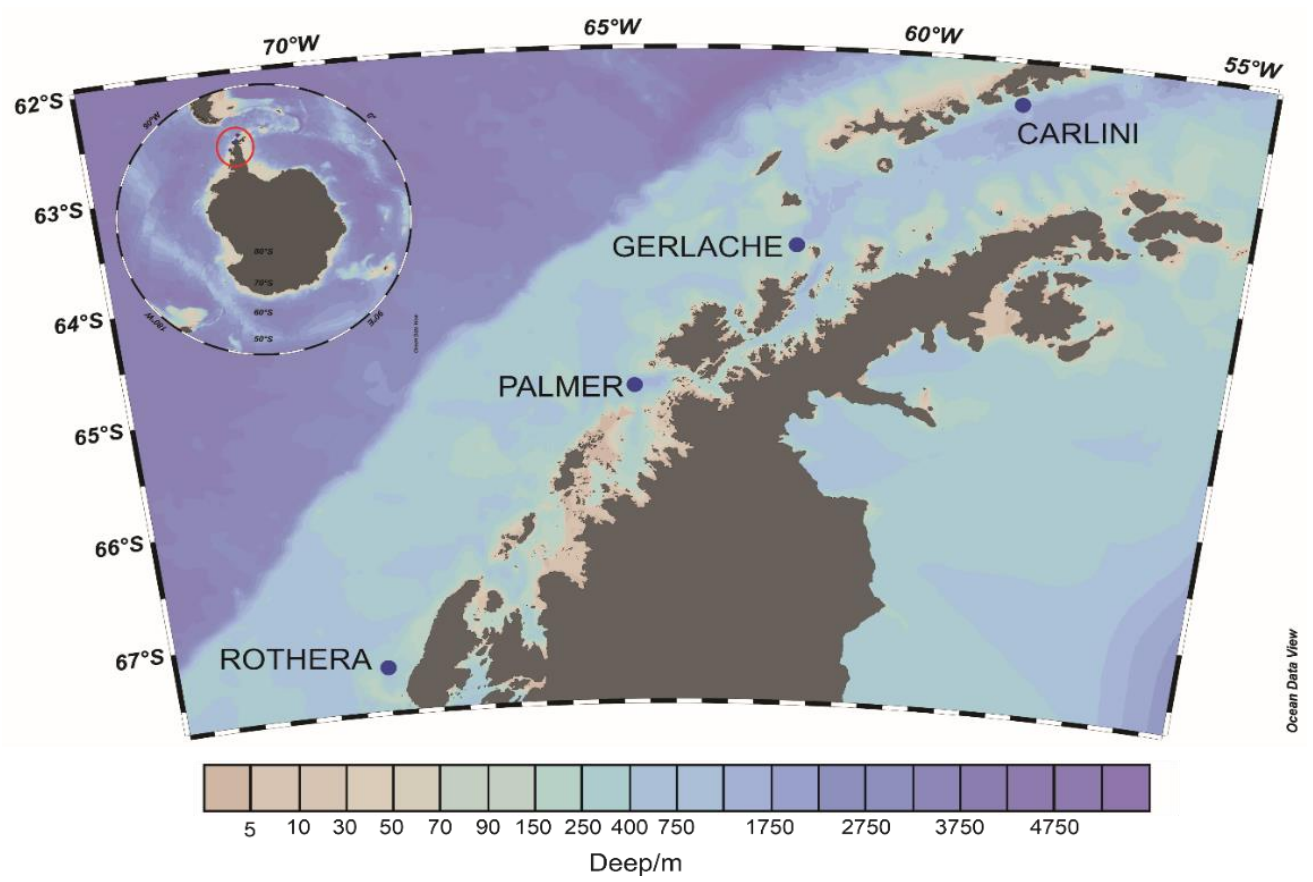

Figure 1. Locations near the Gerlache Strait and the Rothera, Palmer, and Carlini research stations for which sea-surface temperature (SST) time series were compiled.

Daily data from each sensor were processed; scenes containing navigation errors or low-quality pixels (according to a set of Level-2 flags) were identified and discarded, leaving a total of 17,175 daily SST scenes. These data were used to construct average January SST multi-sensor composite scenes for the years 2001 to 2020, following the criteria proposed by Kahru et al. [26,27] using the software package WIM/WAM [28]. The time series of January SST for the four study locations along the WAP were extracted (Figure 1) using the WIM-WAM routines.

The study locations are in the vicinity of the Carlini (Argentina), Palmer (USA), and Rothera (UK) Antarctic research stations. The fourth location, the Gerlache Strait (Gerlache), was selected based on the sampling grid used by the Third and Fourth Colombian Antarctic expeditions carried out in 2017 and 2018, respectively, which focused on this strait [11].

Time series of standardized January thermal anomalies were constructed following the criteria proposed by Santamaria-del-Angel et al. [29] using the Z transformation (Equation (1)):

$$
Z_{S S T}=\frac{(X-\bar{X})}{S D}
$$

where $Z_{S S T}$ is the standardized thermal anomaly for January of a given year at each of the four locations $\left(Z_{S S T}\right.$ Carlini, $Z_{S S T}$ Gerlache, $Z_{S S T}$ Palmer, and $Z_{S S T}$ Rothera), $X$ is the SST on January of the given year, $\bar{X}$ is the average $S S T$ over the entire series, and $S D$ is the standard deviation over the entire series.

For each locality and $Z_{S S T}$, and following the criteria by $\mathrm{Chen}$ and $\mathrm{Wu}$ [30], the power spectral density was estimated with the periodogram method. The statistical significance of the power peaks was derived by plotting the F-values for each spectrum following the criteria by Morales-Acuña et al. [31] and Di Matteo et al. [32].

To determine the similarity between locations based on $Z_{S S T}$, we conducted a correlation analysis between time series using Pearson's linear correlation coefficient. The data were displayed in a hierarchical dendrogram following the criteria by Schonlau [33], with Pearson's coefficient as a similarity function and the average linkage clustering method to create the clusters.

The clusters obtained were verified using a multiple-contrast approximation applied to the variance of non-standardized series, based on the F index and following the consid- 
erations of Jamshidian and Jalal [34]. The null hypothesis was that both series had equal variances. Before running these multiple contrasts, we confirmed that each time series fitted a Gaussian distribution using the Q-Q test described by Liang et al. [35].

Monthly data for the Southern Oscillation Index (SOI) [36] (since 1876) and the Southern Annular Mode (SAM) [37-39], also known as the Antarctic Oscillation [40] (since 1957), were compiled in order to correlate temperature variability in the WAP with other phenomena. January data for each index's entire time series were retrieved: SOI, January 1876 to January 2020; and SAM, January 1957 to January 2020. Standardized January anomalies for each index $\left(Z_{S O I}\right.$ and $Z_{S A M}$, respectively) were computed using Equation (1); the mean and standard deviation of each index were computed over the entire data sets [29].

Three approaches were tested to examine the relation between the thermal anomalies at the four locations $\left(Z_{S S T}\right.$ Carlini, $Z_{S S T}$ Gerlache, $Z_{S S T}$ Palmer, and $Z_{S S T}$ Rothera $)$ and the $Z_{S O I}$ and $Z_{S A M}$ values $(n=20)$. First, Pearson's and Spearman's correlation coefficients between $Z_{S S T}$ and either $Z_{S O I}$ or $Z_{S A M}$ were calculated separately following the criteria of Santamaria-del-Angel et al. [41]. The statistical significance of the indices was evaluated [42], and the results were interpreted following the criteria of $\mathrm{Mu}$ et al. [43]. Critical values tables were taken from [44] for Pearson's correlation coefficient and [45] for Spearman's correlation coefficient.

The second approach examined the joint variation in $Z_{S S T}, Z_{S O I}$, and $Z_{S A M}$ using a principal component analysis (PCA), following the criteria of Santamaria-del-Angel et al. [46] and applying Kaiser's rule, selecting only those components with eigenvalues higher than or equal to 1 [47-51]. The PCA results were further examined by constructing a multidimensional vector plot derived from a factor analysis. In this plot, vectors having the same direction and magnitude indicate that the variables represented show identical behaviors. Variables are associated when the respective vectors form an angle either lower than $45^{\circ}$ (positive association) or about $180^{\circ}\left( \pm 22.5^{\circ}\right)$ (inverse association). This plot represents vectors in a hyperspace and, thus, no axes are drawn.

The third approach explored the agreement between variations in $Z_{S S T}$ Stations and variations in $Z_{S O I}$ or $Z_{S A M}$. For this purpose, the relative power index $\left(P r_{\text {index }}\right)$ (Equation (2)) described by Navarro-Fierro [52] was calculated, following the criteria of Santamaria-delAngel et al. [53].

$$
P r_{\text {index }}=1-\left(\frac{\frac{c}{r_{2}}}{\frac{a}{r_{1}}}\right)
$$

Based on the results from the first two approaches, this index was calculated for two different scenarios. The first scenario explored the relation between positive values of the indices and low temperatures. In this scenario, Equation (2) is interpreted as follows: $a$ is the number of cases with a negative value of $Z_{S S T}$ Stations and positive values of $Z_{S O I}$ or $Z_{S A M}, c$ is the number of cases with negative $Z_{S S T}$ Stations and negative $Z_{S O I}$ or $Z_{S A M}, r_{1}$ is the total number of cases with positive $Z_{S O I}$ or $Z_{S A M}$, and $r_{2}$ is the total number of cases with negative $Z_{S O I}$ or $Z_{S A M}$. The $P r_{\text {index }}$ can adopt any value; in general, positive $P r_{\text {index }}$ values indicate that positive $Z_{S O I}$ or $Z_{S A M}$ values coincide with negative thermal anomalies (i.e., cooling conditions) at the station. Negative $P r_{\text {index }}$ values imply that positive values of $Z_{S O I}$ or $Z_{S A M}$ coincide with positive thermal anomalies (warming conditions). The higher the absolute value of $P r_{\text {index }}$, the stronger the relationship.

The second scenario explored the opposite relation versus scenario 1, that is, how negative values of the indices affect positive temperature values. In this scenario, Equation (2) is interpreted as follows: $a$ is the number of cases with a positive value of $Z_{S S T}$ Stations and negative $Z_{S O I}$ or $Z_{S A M}, \mathrm{c}$ is the number of cases with positive $Z_{S S T}$ Stations and positive $Z_{S O I}$ or $Z_{S A M}, r_{1}$ is the total number of cases with negative $Z_{S O I}$ or $Z_{S A M}$, and $r_{2}$ is the total number of cases with positive $Z_{S O I}$ or $Z_{S A M}$. The $P r_{\text {index }}$ can adopt any value; in general, positive $P r_{\text {index }}$ values indicate that negative values of $Z_{S O I}$ or $Z_{S A M}$ coincide with positive thermal anomalies (i.e., warming conditions) at the station. Negative $P r_{\text {index }}$ values imply that negative values of $Z_{S O I}$ or $Z_{S A M}$ coincide with negative thermal anomalies (cooling conditions). The higher the absolute value of $P r_{\text {index }}$, the stronger the relationship. 


\section{Results}

The time series of SST at the WAP stations (Figure 2) show warm peaks (typically lasting one summer) followed by cold episodes lasting four to five summers. The variability of a time series can be evaluated using both its standard deviation (SD) and its range, i.e., the difference between the maximum and the minimum values (Table 1). Thus, a north-tosouth variability gradient can be observed (Table 1), with Carlini and Rothera as the least and most variable stations, respectively (Figure 2a,d, respectively). Figure 2 and Table 1 show that the WAP can be divided into two zones: the northern zone, represented by Carlini and Gerlache (Figure 2a,b), and the southern zone, represented by Palmer and Rothera (Figure 2c,d). The northern zone shows a lower variability (SD $=0.330$ and 0.400, respectively) versus the southern zone ( $\mathrm{SD}=0.722$ and 0.826 , respectively), as presented in Table 1.
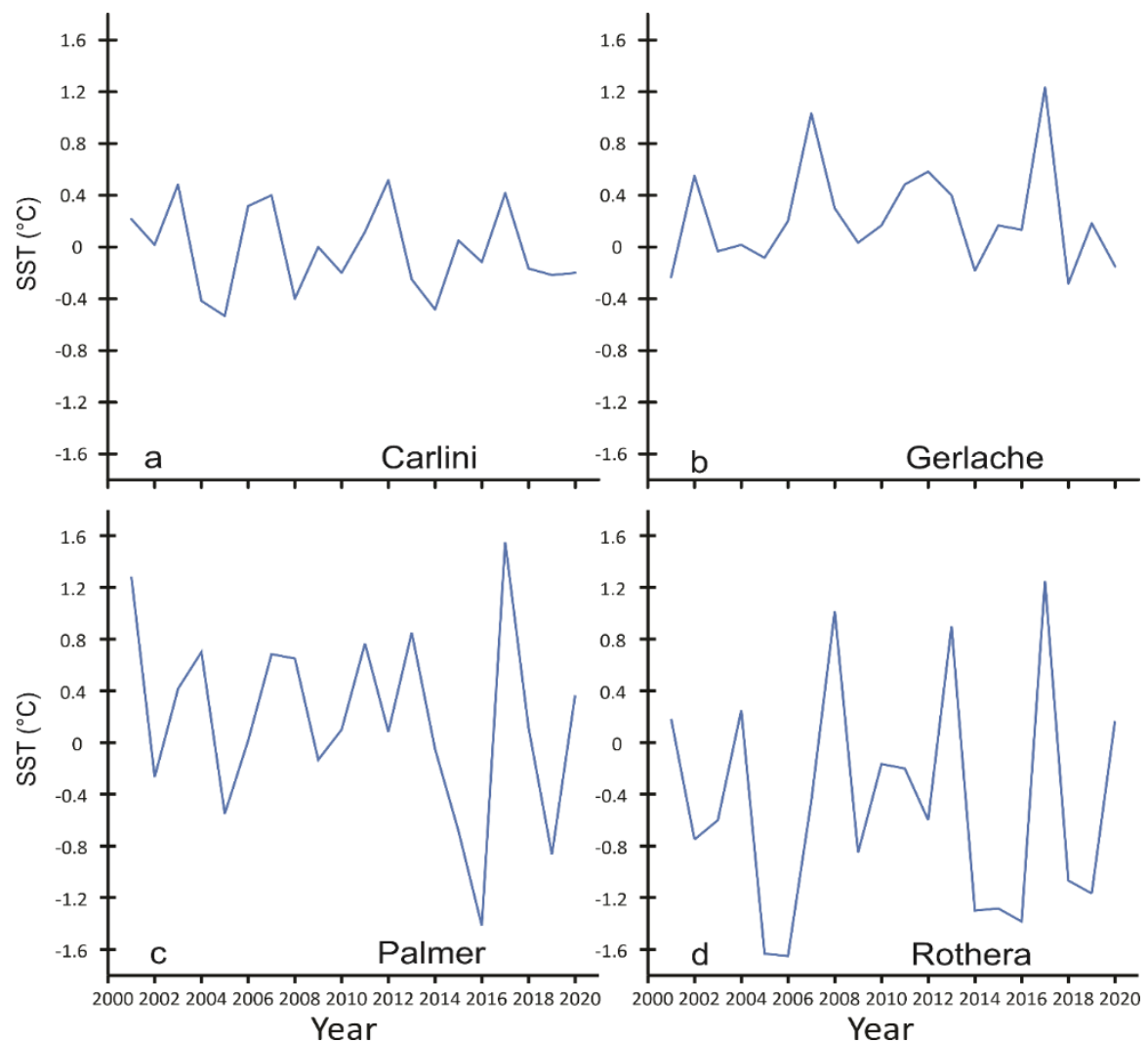

Figure 2. Time series of January SST $\left({ }^{\circ} \mathrm{C}\right)$ at (a) Carlini, (b) Gerlache, (c) Palmer, and (d) Rothera sites.

Table 1. Descriptive statistics of the time series (2001-2020) of January SST $\left({ }^{\circ} \mathrm{C}\right)$ at four locations in the West Antarctic Peninsula (WAP).

\begin{tabular}{cccccc}
\hline Station & $\mathbf{n}$ & $\begin{array}{c}\text { Mean } \\
\left({ }^{\circ} \mathbf{C}\right)\end{array}$ & $\begin{array}{c}\text { SD } \\
\left({ }^{\circ} \mathbf{C}\right)\end{array}$ & $\begin{array}{c}\text { Minimum } \\
\left({ }^{\circ} \mathbf{C}\right)\end{array}$ & $\begin{array}{c}\text { Maximum } \\
\left({ }^{\circ} \mathbf{C}\right)\end{array}$ \\
\hline Carlini & 20 & -0.022 & 0.330 & -0.533 & 0.517 \\
Gerlache & 20 & 0.226 & 0.400 & -0.283 & 1.233 \\
Palmer & 20 & 0.181 & 0.727 & -1.417 & 1.550 \\
Rothera & 20 & -0.467 & 0.876 & -1.650 & 1.250 \\
\hline
\end{tabular}

Comparing the four time series of SST, the correlation analysis and its dendrogram (Figure 3) clearly show the two zones previously described. 


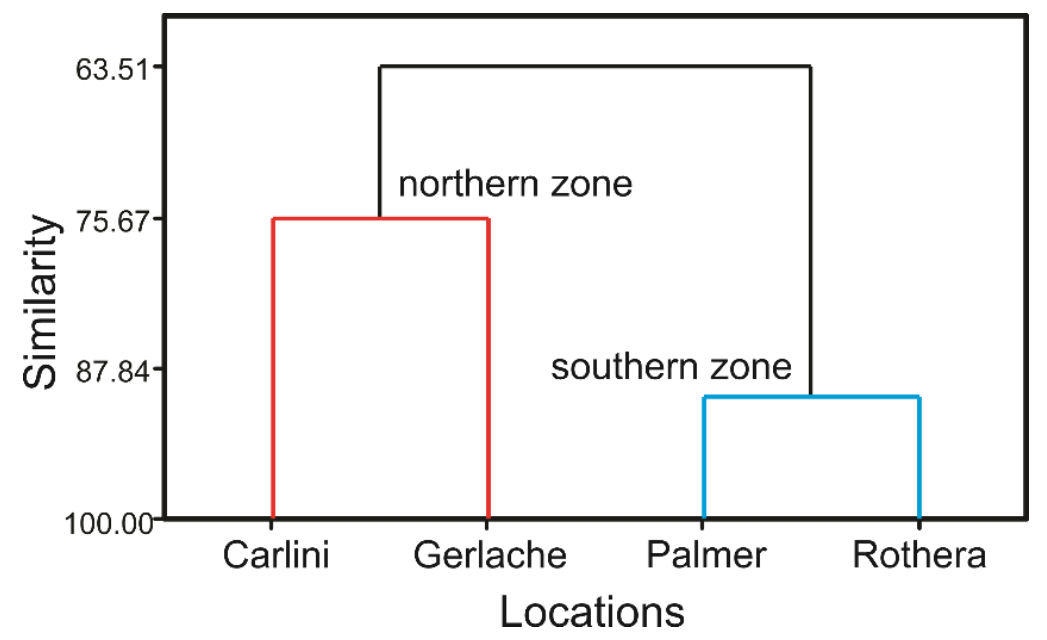

Figure 3. Dendrogram of the correlation analysis of the time series of localities based on Pearson's correlation coefficient as a similarity function and the average linkage clustering method.

As the time series of each locality shows a Gaussian distribution (Table 2), the formation of the northern and southern zones just described were confirmed statistically through multiple comparisons of variances (Table 3).

Table 2. Results of the $\mathrm{Q}-\mathrm{Q}$ test for the Gaussian distribution of each series $(n=20$ and alpha error $=5 \%$ ). In the Decision column, the Gaussian distribution is denoted as G.D.

\begin{tabular}{ccccc}
\hline & Q-Qcal & Q-Qcrit & Comparison & Decision \\
\hline Carlini & 0.97 .98 & 0.9498 & Q-Qcal $>$ Q-Qcrit & The data have a G.D. \\
Gerlache & 0.954112 & 0.9498 & Q-Qcal $>$ Q-Qcrit & The data have a G.D. \\
Palmer & 0.992129 & 0.9498 & Q-Qcal $>$ Q-Qcrit & The data have a G.D. \\
Rothera & 0.975972 & 0.9498 & Q-Qcal $>$ Q-Qcrit & The data have a G.D. \\
\hline
\end{tabular}

Table 3. Results of the multiple-contrast approximation based on the F-test. We used $n=20$ for all series and an alpha error $=5 \%$ in each contrast.

\begin{tabular}{ccccc}
\hline Contrast & Fcal & Fcrit & Comparison & Decision \\
\hline Carlini vs. Gerlache & 1.470 & 2.168 & Fcal $<$ Fcrit & Equal variances \\
Carlini vs. Palmer & 4.851 & 2.168 & Fcal $>$ Fcrit & Different variances \\
Carlini vs. Rothera & 7.047 & 2.168 & Fcal $>$ Fcrit & Different variances \\
Gerlache vs. Palmer & 3.301 & 2.168 & Fcal $>$ Fcrit & Different variances \\
Gerlache vs. Rothera & 4.795 & 2.168 & Fcal $>$ Fcrit & Different variances \\
Palmer vs. Rothera & 1.453 & 2.168 & Fcal $<$ Fcrit & Equal variances \\
\hline
\end{tabular}

The result of the test described above (Table 3) indicates that the stations Carlini and Gerlache had equal variances (first contrast) and Palmer and Rothera (last contrast) showed equal variances. The remaining contrasts were tested for homoscedasticity and showed different variances.

The standardized thermal anomalies for January at each station (Figure 4) clearly show the warm episodes described above. 


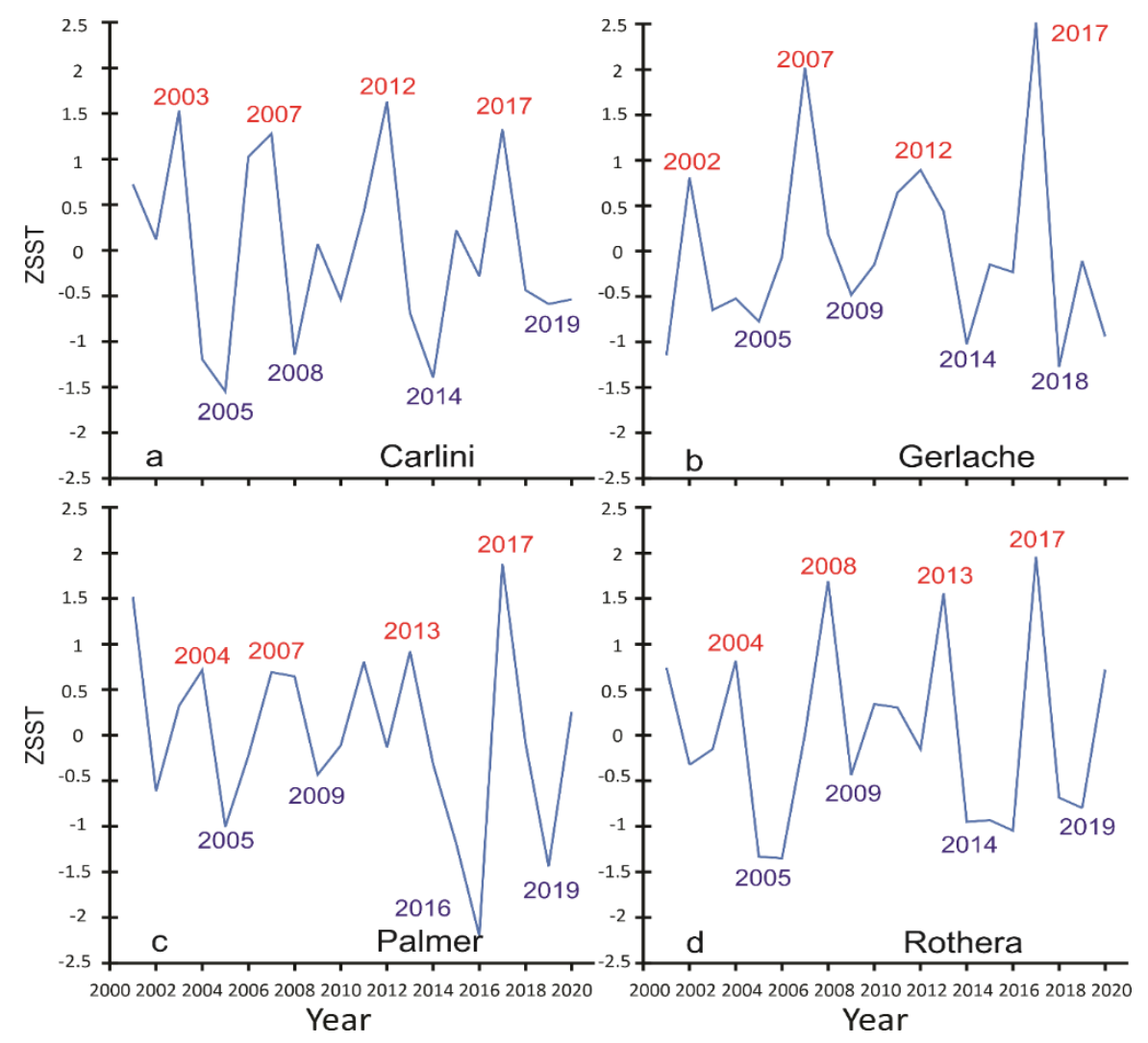

Figure 4. Time series of standardized SST anomaly at (a) Carlini, (b) Gerlache, (c) Palmer, and (d) Rothera sites. Red and blue numbers indicate the year of occurrence of warm and cool episodes, respectively.

Except for Carlini, the summer of 2017 has been the warmest episode so far in the 21st century. This unusually warm year was followed by a markedly cold period (e.g., Gerlache (Figure 4b) and Palmer (Figure 4c) stations). Overall, the Carlini (Figure 4a) and Gerlache (Figure $4 \mathrm{~b}$ ) stations showed similar patterns of alternating warm and cold periods, different from those shown by the Palmer (Figure 4c) and Rothera (Figure 4d) stations, which were, in turn, similar to each other. This pattern further supports the idea of distinct northern and southern regions in the WAP.

The graphic analysis of power spectra for the standardized series (Figure 5) considering the critical F value reveal that only Carlini (Figure 5a) and Gerlache (Figure 5b) showed a noticeable peak in the power spectrum, corresponding to a period of five years for both sites. On the other hand, the power spectra for Palmer (Figure 5c) and Rothera (Figure 5d) showed no marked peaks.

Figure 6 shows isotherm maps for the WAP. These maps clearly show the spatial distribution of warm waters (SST $\geq 0{ }^{\circ} \mathrm{C}$ ) during the austral summer under warm (2002, 2007, 2012, and 2017) or cold (2005, 2009, 2014, and 2018) episodes.

The $0{ }^{\circ} \mathrm{C}$ isotherm (Figure 6) represents the front between cold and warm waters along the WAP. During warm episodes, the warm-water front reaches the coastline of the peninsula (Figure 6a,c,e,g), being particularly marked in 2007 (Figure 6c), 2012 (Figure 6e), and 2017 (Figure 6g). In contrast, the front appears farther away from the coast of the peninsula during cold episodes (Figure $6 \mathrm{~b}, \mathrm{~d}, \mathrm{f}, \mathrm{h}$ ). The lower the temperature during a cold episode, the farther away from the WAP the thermal front is located (e.g., in 2014 (Figure 6f)). 

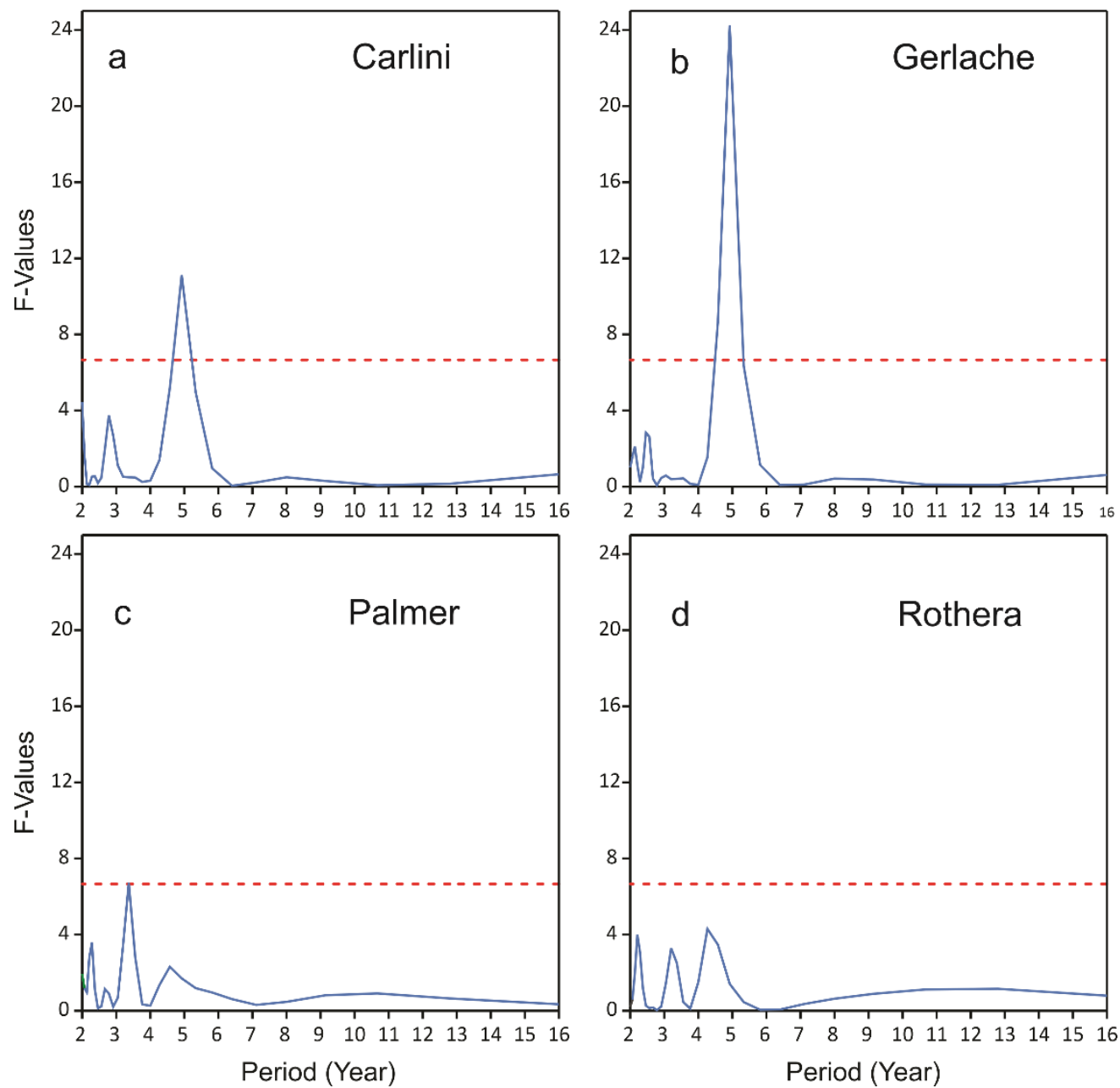

Figure 5. Power spectra derived by the periodogram method for the time series of standardized SST anomalies at (a) Carlini, (b) Gerlache, (c) Palmer, and (d) Rothera sites. The dashed red line represents the critical F value (Fcrit) at an alpha error of $5 \%$; Fcrit $=6.66$ in all cases .

Three approaches were tested to examine the relation between $Z_{S S T}$ and the $Z_{S O I}$ and $Z_{S A M}$ values. First, Pearson's and Spearman's correlation coefficients were calculated separately for each station (Table 4). Only the Palmer station showed a significant (Pearson's and Spearman's) negative correlation with SAM (Table 4), i.e., when SAM is high, the temperature is low.

Table 4. Correlation analyses between $Z_{S S T}$ and $Z_{S A M}$ or $Z_{S O I}$. Values of Pearson's ( $\mathrm{r}_{\text {Pearson }}$ ) and Spearman's ( $\mathrm{r}_{\text {Spearman }}$ ) correlation coefficients are shown. Statistically significant values are shown in boldface. Threshold critical values $[44,45]$ for alpha error $=0.05$ and $n=20$ are $\mathrm{r}_{\text {Pearson }}=0.444$ and $\mathrm{r}_{\text {Spearman }}=0.3805$.

\begin{tabular}{ccccc}
\hline \multirow{2}{*}{ Station } & \multicolumn{2}{c}{ SAM } & \multicolumn{2}{c}{ SOI } \\
\cline { 2 - 5 } & $\mathbf{r}_{\text {Pearson }}$ & $\mathbf{r}_{\text {Spearman }}$ & $\mathbf{r}_{\text {Pearson }}$ & $\mathbf{r}_{\text {Spearman }}$ \\
\hline Carlini & -0.258 & -0.209 & 0.087 & 0.071 \\
Gerlache & -0.264 & -0.103 & -0.070 & 0.038 \\
Palmer & $-\mathbf{0 . 4 7 6}$ & $-\mathbf{0 . 4 2 4}$ & 0.331 & 0.120 \\
Rothera & -0.233 & -0.207 & 0.049 & -0.064 \\
\hline
\end{tabular}



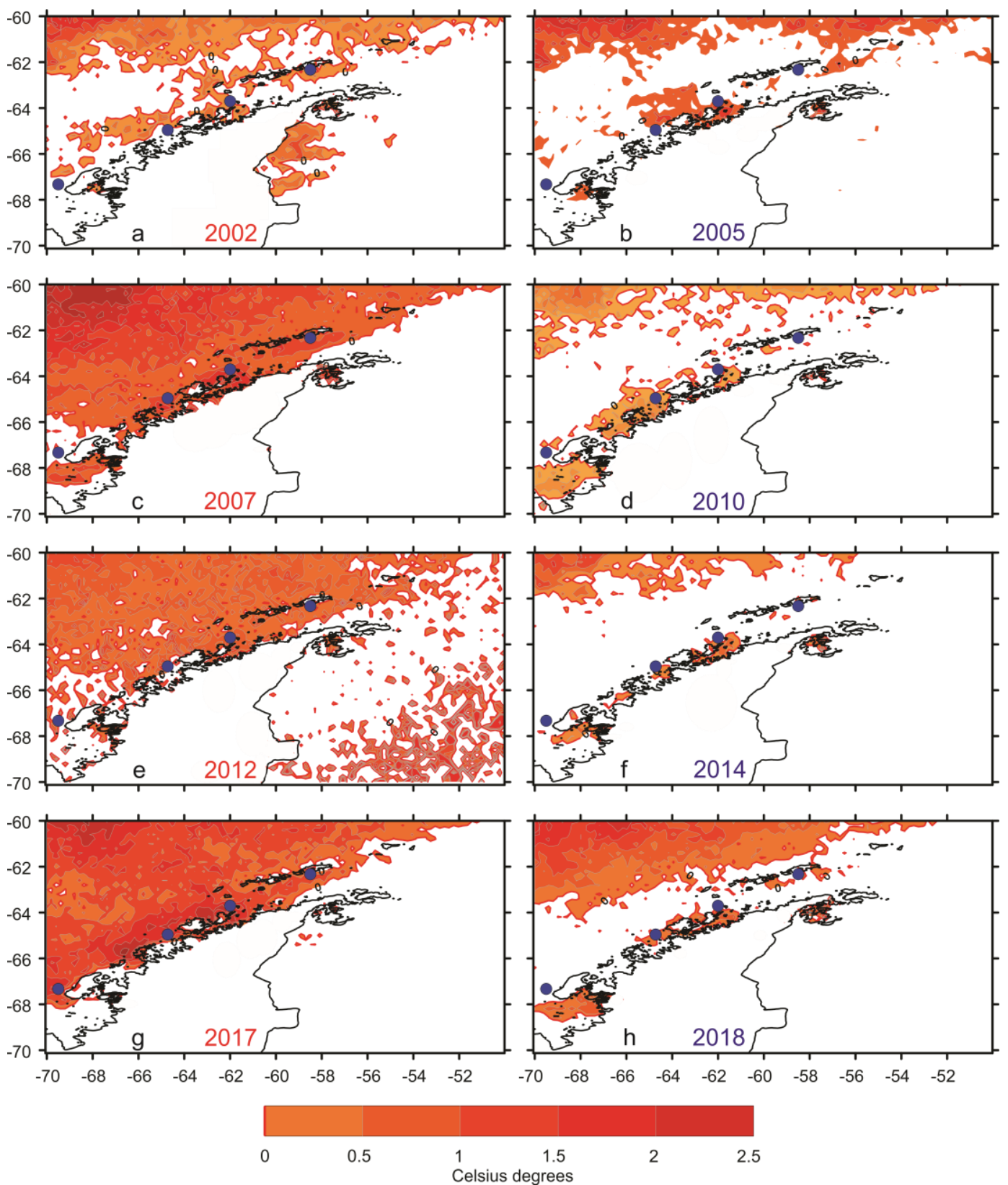

Figure 6. Location of the warm front at the WAP in the year with a warm $(\mathbf{a}, \mathbf{c}, \mathbf{e}, \mathbf{g})$ or cool $(\mathbf{b}, \mathbf{d}, \mathbf{f}, \mathbf{h})$ January.

Based on the correlation matrix of standardized variables (Table 5), a second approach was used to examine the joint variation of $Z_{S S T}$ Stations, $Z_{S O I}$, and $Z_{S A M}$ by performing a PCA (Table 6).

Table 5. Correlation matrix used to develop the principal component analysis of $Z_{S S T}, Z_{S O I}$, and $Z_{S A M}$.

\begin{tabular}{ccccccc}
\hline & Carlini & Gerlache & Palmer & Rothera & SOI & SAM \\
\hline Carlini & 1.000 & 0.516 & 0.301 & 0.055 & 0.087 & -0.258 \\
Gerlache & 0.516 & 1.000 & 0.331 & 0.394 & -0.070 & -0.264 \\
Palmer & 0.301 & 0.331 & 1.000 & 0.803 & 0.331 & -0.476 \\
Rothera & 0.055 & 0.394 & 0.803 & 1.000 & 0.049 & -0.233 \\
SOI & 0.087 & -0.070 & 0.331 & 0.049 & 1.000 & -0.030 \\
SAM & -0.258 & -0.264 & -0.476 & -0.233 & -0.030 & 1.000 \\
\hline
\end{tabular}


Table 6. Results from the principal component analysis of $Z_{S S T}, Z_{S O I}$, and $Z_{S A M}$.

\begin{tabular}{|c|c|c|c|}
\hline \multicolumn{4}{|c|}{ Eigenanalysis of the Correlation Matrix } \\
\hline & PC1 & PC2 & PC3 \\
\hline Eigenvalue & 2.526 & 1.202 & 1.002 \\
\hline Proportion of total variance accounted for & 0.421 & 0.200 & 0.167 \\
\hline Cumulative proportion of total variance accounted for & 0.421 & 0.621 & 0.788 \\
\hline \multicolumn{4}{|c|}{ Loadings of the Variables on Each Component } \\
\hline & PC1 & PC2 & PC3 \\
\hline SOI & -0.229 & -0.605 & 0.723 \\
\hline SAM & 0.605 & -0.083 & -0.007 \\
\hline Carlini & -0.561 & 0.544 & 0.499 \\
\hline Gerlache & -0.667 & 0.528 & -0.035 \\
\hline Palmer & -0.889 & -0.366 & -0.064 \\
\hline Rothera & -0.759 & -0.320 & -0.475 \\
\hline
\end{tabular}

The results (Table 6) showed that only the first three principal components were significant (eigenvalues equal to or greater than 1), jointly accounting for $78.8 \%$ of the total variation. The most outstanding finding is that $Z_{S O I}$ was the only variable related to the third principal component and showed no relation with $Z_{S S T}$ Stations or $Z_{S A M}$. The four thermal anomalies, $Z_{S S T}$, were inversely associated with $Z_{S A M}$ on the first principal component (the one that accounts for the largest fraction of the total variance), indicating that high SAM values coincide with low temperatures at the four stations, and vice versa.

Although the time series of the four stations were associated with the first component, indicating that they covary, the Palmer and Rothera stations, located in the southern zone of the WAP, had higher loadings ( -0.889 and -0.759 , respectively) than the northern zone stations (Carlini, -0.561 ; Gerlache, -0.667$)$.

Figure 7 shows the plot of the factor analysis. This plot evidences the difference between the Palmer and Rhotera stations (southern zone of the WAP) and the Carlini and Gerlache stations in the northern zone and the inverse association between SAM and the SST anomalies at the stations. Once again, the SOI shows no relation with either SAM or the SST anomalies.

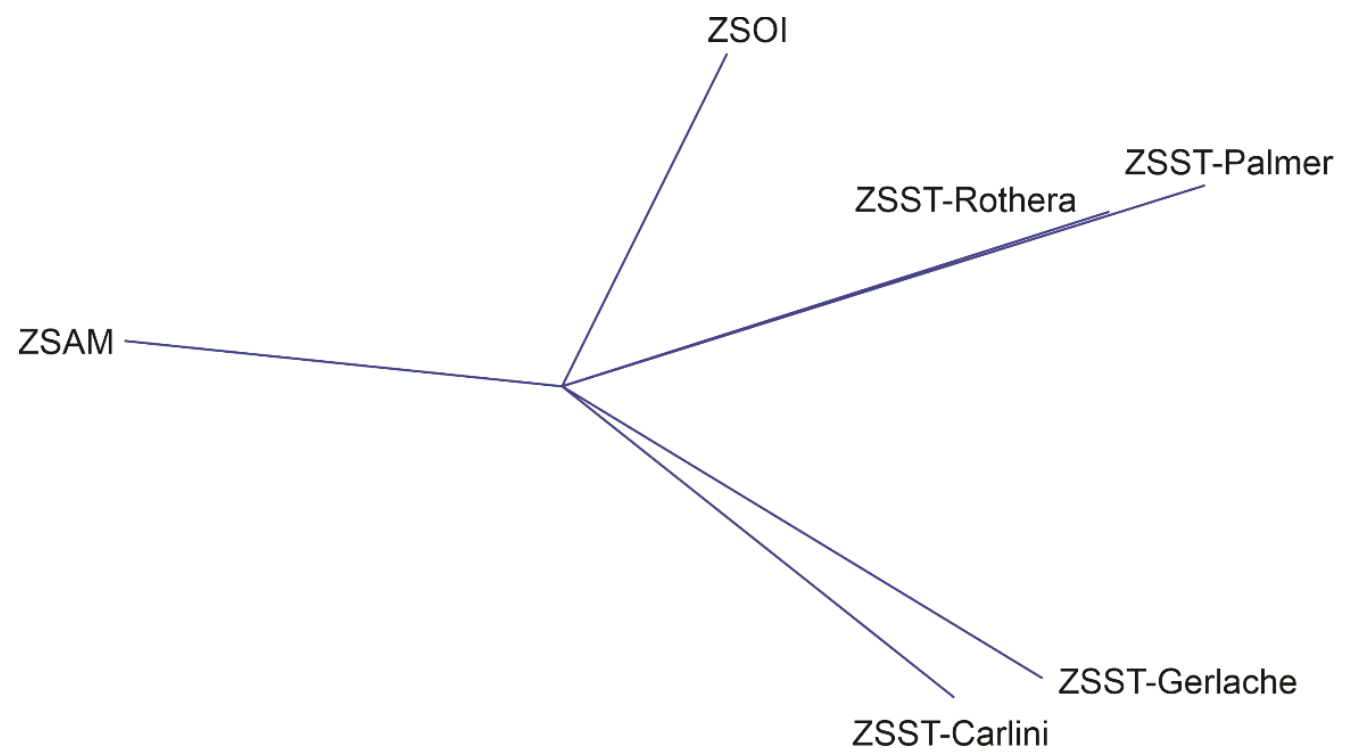

Figure 7. Multidimensional vector plot derived from a factor analysis of the $Z_{S S T}, Z_{S A M}$, and $Z_{S O I}$ in the WAP. The plot shows the loadings of each variable in the eigenvector matrix. As a vector multidimensional plot, this figure has no axes. 
The third approach evaluated, in the first scenario, the extent to which positive values of the standardized SOI or SAM anomalies matched low temperatures (Table 7); the second scenario evaluated the opposite condition, that is, the extent to which negative values of $Z_{S O I}$ or $Z_{S A M}$ were consistent with high temperatures (Table 8). In the first scenario (Table 7), $P r_{\text {index }}$ had positive values in all stations, indicating that high SAM values (positive $Z_{S A M}$ values) coincided with negative thermal anomalies in all the stations, denoting cooling episodes. The zero value recorded in the Carlni station shows that such a relationship does not hold therein. The two southern stations (Palmer and Rothera) denoted the same positive value, 0.428 , meaning that $42.8 \%$ of the negative thermal anomalies (cold temperatures) recorded in these stations coincided with positive $Z_{S A M}$ values. Conditions of positive $Z_{S O I}$ values showed a clear split between the northern (Carlini and Gerlache stations, with negative values) and southern (Palmer and Rothera stations, with positive values) zones. The negative values for the northern zone indicate that positive $Z_{S O I}$ conditions coincided with warm waters; $90.9 \%$ of the positive SST anomalies recorded at the Carlini station coincided with high $Z_{S O I}$ conditions. In the southern zone, $31.8 \%$ of cold conditions were recorded under conditions of high $Z_{S O I}$.

Table 7. Values for the relative power index, $P r_{i n d e x}$, evaluating the coincidence of high Southern Oscillation Index (SOI) or Southern Annular Mode (SAM) conditions with low temperatures at each station.

\begin{tabular}{ccc}
\hline Negative $\boldsymbol{Z}_{S S T}$ at & Positive $\boldsymbol{Z}_{\text {SOI }}$ & Positive $\boldsymbol{Z}_{S A M}$ \\
\hline$Z_{S S T}$ Carlini & -0.909 & 0.000 \\
$Z_{S S T}$ Gerlache & -0.309 & 0.143 \\
$Z_{S S T}$ Palmer & 0.318 & 0.428 \\
$Z_{S S T}$ Rothera & 0.318 & 0.428 \\
\hline
\end{tabular}

Table 8. Values for the relative power index, $P r_{\text {index }}$, evaluating the coincidence of low SOI or SAM conditions with high temperatures at each station.

\begin{tabular}{ccc}
\hline Positive $Z_{S S T}$ at & Negative $Z_{S O I}$ & Negative $Z_{S A M}$ \\
\hline$Z_{S S T}$ Carlini & -0.833 & 0.000 \\
$Z_{S S T}$ Gerlache & -0.629 & 0.250 \\
$Z_{S S T}$ Palmer & 0.388 & 0.500 \\
$Z_{S S T}$ Rothera & 0.388 & 0.500 \\
\hline
\end{tabular}

The second scenario evaluated the extent to which low index values coincided with high temperatures (Table 8). This scenario revealed the same overall pattern described above (Table 7) for $Z_{S O I}$. The northern zone showed negative values, indicating the presence of cold waters during conditions of negative $Z_{S O I}$. On the other hand, $38.8 \%$ of the warm events recorded in the southern zone coincided with negative $Z_{S O I}$ values. No coincidence was found between negative values of the $Z_{S A M}$ index and high temperatures at the Carlini station; in contrast, some of the high temperatures recorded at the other stations coincided with negative $Z_{S A M}$ values. The southern zone stations had identical values and responded more strongly to negative $Z_{S A M}$ values, whereas the northern zone (Gerlache) did so only moderately.

\section{Discussion}

SST variability in the WAP (Figures 2, 4 and 5; Table 1) shows a clear pattern, with a single warm peak (one summer) followed by a cold period (four to five summers). This five-year periodicity showed a significant signal for the Carlini (Figure 5a) and Gerlache (Figure 5b) sites. The apparent absence of this pattern in the Palmer (Figure 5c) and Rothera (Figure $5 \mathrm{~d}$ ) sites may be a consequence of coastal morphology, as well as the interactions between fjords and the dynamics of marine ice, all of which may produce 
greater variations in SST in these two locations (Figure 2, Tables 1 and 3), relative to the Carlini and Gerlache sites.

Based on the above plus the findings of this study (Table 1, Table 3, Table 6, Table 7, Table 8 and Figures 2-5 and 7), the WAP can be clearly split into two zones: the northern zone (Carlini and Gerlache sites) and the southern zone (Palmer and Rothera sites). The specifics supporting this division into two zones are discussed below.

The maps of SST distribution show that warm waters (delimited by the $0{ }^{\circ} \mathrm{C}$ isotherm) reach the peninsula coastline during warm conditions (Figure $6 c, e, g$ ) but not under cold conditions (Figure $6 \mathrm{~b}, \mathrm{~d}, \mathrm{f}, \mathrm{h}$ ). During frigid periods (for example, the year 2014; Figure 6f), the $0{ }^{\circ} \mathrm{C}$ thermal front is farther away from the WAP. The results by Turner et al. [54] also support the idea of regular ingress of warm water to the WAP coasts.

Changes in ocean surface dynamics affect the ecology and physiology of marine organisms and of entire communities through ecological interactions in the food web [7,55]. Thus, the inflow of warm waters onto the WAP coast every five years or so likely affects food webs over the entire region. During the III Colombian Scientific Expedition to the Antarctic (Almirante Padilla; January 2017, a warm year; Figure 6g), numerous large salps were observed on the water surface, while krill was absent from the zooplankton trawls carried out in the Gerlache Strait. The following year and across the same grid of sampling stations, the IV Colombian Scientific Expedition to the Antarctic (Almirante Tono; January 2018, a cold year; Figure 6h) found that salps had disappeared, krill was present in zooplankton samples, and marine mammals were common in the region.

In the Antarctic, krill is associated with summer phytoplankton blooms, while salps are found in warmer, oligotrophic waters [56]. The phytoplankton-krill relationship can affect higher trophic levels, including penguins [9]. Thus, the seasonal succession of krill and salps in the Antarctic may serve as an indicator of environmental changes [57], since the food web in this region is highly complex and involves multiple interactions [58].

The inflow of warm waters onto the WAP coast might be driven by the strengthening or weakening of ocean currents that lead to the inflow of warm surface waters onto the WAP coasts. The major current in the region is the Antarctic Circumpolar Current, which flows eastward, surrounding the Antarctic [59] and linking the main ocean basins along its trajectory. The Antarctic Circumpolar Current is, therefore, considered a vital component of the global climate system [60]. It is the only current in the world that surrounds the polar axis, almost uninterrupted by continental masses, and is delimited by two fronts located along the polar circle: the Polar Front, which is closer to the Antarctic, and the Subantarctic Front, which is more distant from the continent $[61,62]$. The area north of the Subantarctic Front is the Subantarctic Zone, the area between the Polar Front and the Subantarctic Front is the South Polar Front Zone, and the area south of the Polar Front to the coast is the Antarctic Zone [62]. Giglio and Johnson [63] pointed out that these zones show distinctive temperature and salinity conditions; based on their locations, the Subantarctic Zone, South Polar Front Zone, and Antarctic Zone can be considered warm, lukewarm, and cold waters, respectively.

The only potential restriction along the Antarctic Circumpolar Current trajectory is the approximately $800 \mathrm{~km}$ wide bottleneck formed by the Drake Strait between Patagonia and the WAP (Figure 1) [61]. This zone is regarded as a critical area as it markedly influences the Antarctic Circumpolar Current flow [60]. Various studies have sought to delimit the position and fluctuations of the Antarctic Circumpolar Current in this zone, which has proved a challenging task. Such studies have used models [64-67] constructed using satellite [68,69] or in situ recorded data [62], showing that the zone close to the WAP is complex and inhomogeneous [70], with more than two fronts delimited therein. Tarakanov and Gritsenko [62] mentioned that by January 2010, the fine structure of the Antarctic Circumpolar Current was made up of 11 individual fronts, while 9 individual fronts were detected in October-November 2011. The same authors reported that these fronts were found in various combinations at the Drake Strait. 
Since the South Polar Front Zone contains lukewarm waters and the Antarctic Zone cold waters, with the Polar Front marking the boundary between them, the warm waters that reach the WAP every four to five years might be driven by the intrusion of the South Polar Front Zone and the ensuing displacement of the Antarctic Zone during the warm events described in Figure 6.

According to King et al. [71], the WAP is the only part of the Antarctic continental shelf that is subject to intrusions of the Circumpolar Deep Water. The Circumpolar Deep Water is relatively warm and, if it emerges to the surface, would be evidenced by higher surface temperatures. The same authors mentioned that although the mechanisms driving the intrusion of Circumpolar Deep Water onto the WAP are not fully understood yet, these are likely related to the proximity of the Antarctic Circumpolar Current and the morphology of the continental shelf in this region. The Antarctic Circumpolar Current is mostly driven by the wind along its trajectory [61]. Thus, wind fluctuations would influence the spatiotemporal variability of the Antarctic Circumpolar Current in the WAP [71], which, together with the local topography, would produce a marked regional variability in the WAP [72].

Due to this relationship with wind, White and Peterson [59] hypothesized that there might be a teleconnection between the Antarctic Circumpolar Current and ENSO. It is currently known that SAM can strongly influence wind fields in the WAP, thus affecting air and sea-surface temperatures $[7,19,73])$. Consequently, studies on the relationship between the magnitudes of SAM and ENSO and their influence on the WAP environment have raised significant interest in the scientific community [54,74-76]. Stammerjohn et al. [77] outlined how the Antarctic Circumpolar Current can vary with fluctuations in SAM and ENSO, as warm waters reach the WAP at different times (Figure 6).

We tested three approaches to examine ENSO's relation (evaluated in terms of the SOI) and SAM and SST at each location. The first approach used Pearson's and Spearman's correlation coefficients for each station (Table 4). It revealed a significant inverse association (with both coefficients) between SST and SAM only at the Palmer station. This association means that when SAM reaches high values, SST at Palmer station is low. However, although the correlation coefficients for this station were significant (Pearson's $=-0.476$ and Spearman's $=-0.424)$, they showed a relatively weak association. No significant correlation was found between the SOI and SST at any station. These results are consistent with Barnes et al. [72], Clem et al. [78], and Kim et al. [8], who reported null or weak associations. Fogt et al. [79] pointed out that such correlation analyses may not always provide the best information on the variation of this teleconnection with ENSO. Particularly, correlation coefficients do not yield information on the magnitude of each event and may be strongly skewed by atypical values.

The PCA (Table 6) showed that the SOI had a high loading on the third principal component (PC3) and had no relationship with either the SST at the stations (which had high loadings on PC1) or SAM. These results are evident in the vector graph from the factor analysis (Figure 7). Previous studies have also found weak relationships between ENSO and SAM [73,75,79-81] and various interpretations have been put forward: (a) these indices describe phenomena that are independent of each other (no relationship between them) [80]; (b) both indices are governed by a common third factor [81] that differently influences each of them; or (c) there are other independent factors, such as surface buoyancy forcing, that exert a more substantial influence on wind patterns in the Antarctic [73]. The associations between variables summarized by the three significant principal components (Table 6) account for $78.8 \%$ of the total variability. Using a similar approach based on Empirical Orthogonal Functions (EOF), Yeo and Kim [82] found that SAM and the SOI account for only $30 \%$ of the total variability in SST.

SAM had a high loading on PC1 (Table 6), accounting for $42.10 \%$ of the total variability by itself. For its part, the SOI had a high loading on PC3 but accounted for only 16.7\% of the total variability. Our results from the PCA and factor analysis (Table 6; Figure 7) of the relationship between SAM and SST at the different locations showed that SAM was inversely correlated with the standardized SST time series in all the localities. This relation 
means that low temperatures occur when SAM reaches high values and vice versa. Overall, our results showed that SAM might be the primary driver of climate variability in the WAP, while ENSO would play a secondary role.

Previous studies $[7,73,76,78]$ have highlighted the importance of these indices for describing climate variability in the Antarctic, giving an insight into the apparent relationship between ENSO and SAM. Taking each index separately, ENSO could drive climate variability in the WAP only under strong ENSO conditions $[83,84]$. During a strong ENSO event, a considerable Rossby wave train pattern is formed [84], together with considerable wind anomalies [79] that strengthen teleconnections; these, in turn, can be evident in surface waters at high latitudes. According to Yiu and Maycock [85], under such conditions, the relationship between the index and environmental variables in the WAP could be described using more straightforward mathematical approaches (e.g., linear models) in both austral winter and summer conditions.

The statement that SAM is the main driver of climate variability in the WAP should be taken with caution, as this index has been reported to be linked with ozone over the Antarctic [54,76,83,86,87]. Jones et al. [76] reported that the recent positive trend in SAM is related to the increasing depletion of stratospheric ozone. Giglio and Johnson [63] reported that the relation between SAM and atmospheric ozone levels shows neither a seasonal pattern nor a long-term trend.

SAM plays a central role in climate variability in the Antarctic, but the future trends in SAM are still uncertain. Therefore, it is essential that climate models adequately simulate temperature trends and their relationship with and regulation by SAM [76]. These potential associations are likely to be described quantitatively and with more evident patterns three decades from now, when the ozone layer over the Antarctic stabilizes [88], provided no other natural or anthropogenic factor stresses the ozone layer again.

The PCA thoroughly examined the relation of climate variability in the WAP with SAM and ENSO. To study such relations at each of the four locations, we tested the third approach for two contrasting scenarios. The first scenario examined the likelihood of finding low temperatures under high SAM or SOI conditions at each location (Table 7). In contrast, the second scenario reviewed the likelihood of finding high temperatures when the indices had low values, also at each site (Table 8). The results, shown in Table 7, indicate that cold waters at the Carlini location $\left(P r_{\text {index }}=0\right)$ had no relation with high SAM values. The results for the southern locations (Palmer and Rothera, both with $P r_{\text {index }}=0.428$ ) showed that $42.8 \%$ of cold temperatures occurred under conditions of high SAM. This result is consistent with the variability accounted for by PC1 (Table 6) described above.

Regarding high SOI values, a clear difference was observed between the northern (Carlini and Gerlache locations, both with negative values) and southern (Palmer and Rothera, both with positive values) zones of the WAP. The negative values of the northern zone indicate that warm waters occur therein when the SOI has high values. About 90.9\% of the positive SST anomalies recorded at Carlini occurred under high SOI conditions. Likewise, $31.8 \%$ of the cold temperatures recorded in the southern zone occurred under high SOI values.

The second scenario examined how the negative values of the indices affected high temperature values (Table 8 ) and revealed the same patterns as those described in Table 7. In other words, $38.8 \%$ of warm conditions were observed in the southern zone and $60 \%$ of cold conditions were observed in the northern zone under negative $Z_{S O I}$ values. Likewise, when $Z_{S A M}$ had negative values, Carlini did not respond to the index, while the other stations recorded high temperature values. The Palmer and Rothera stations, representing the southern zone, showed identical values and responded more strongly to the index's negative values, whereas the northern zone (Gerlache) displayed a moderate response. This approach clearly showed that the WAP comprises two large zones with distinctive climate variability patterns and that these are differently related to SAM and SOI (Tables 7 and 8). In general, the northern zone (Carlini and Gerlache locations; Figure 2a,b, Figure 3, Figure 4a,b, Figure 5a,b and Figure 7) is less variable (Tables 1 and 3) than the 
southern zone (Palmer and Rothera; Figure 2c,d, Figure 3, Figure $4 c, d$, Figure $5 c, d$ and Figure 7) (Tables 1 and 6 and Figure 7). Kim et al. [8] reported similar patterns based on data recorded in situ.

These zones can be related to the marine ecoregions of the world [89], specifically to the Scotia Sea province (province No. 60) of the Southern Ocean realm (Figure 8). The northern zone of the WAP belongs to the South Shetland Islands ecoregion (ecoregion 222), while the southern zone belongs to the Antarctic Peninsula ecoregion (ecoregion 223). Carlini is located within ecoregion 222 and Palmer and Rothera in ecoregion 223. Palmer and Rothera showed similarly high values in the PCA (Table 6), while Carlini and Gerlache showed similarly low values. Figure 8 suggests that the Gerlache is located at the boundary between these two ecoregions but under greater influence from ecoregion 222, particularly if we consider that these borders are dynamic (refer to [46]).

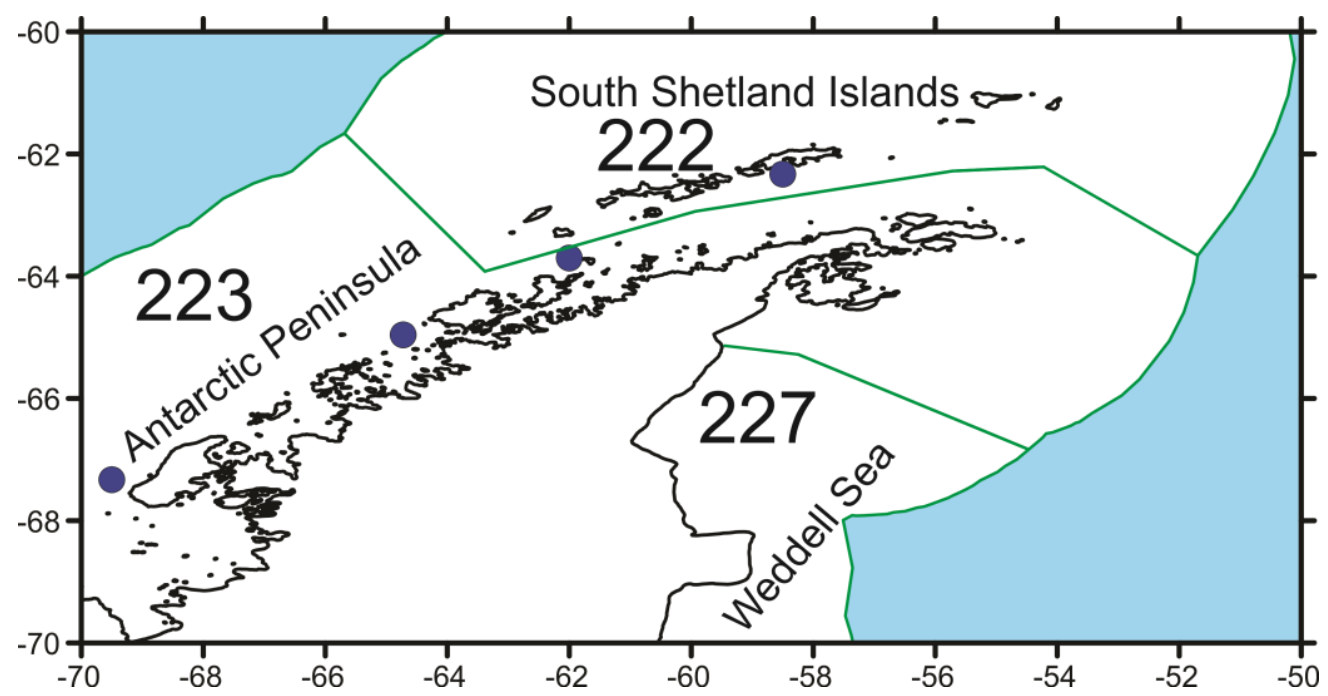

Figure 8. Marine ecoregions of the world [89] at the Antarctic Peninsula. The WAP falls within the Scotia Sea province (province No. 60) and comprises ecoregions 222 and 223. The eastern part of the peninsula falls within the Continental High Antarctic province (province No. 61) and comprises the ecoregion 227. The shapefiles are available at [90]. The study locations are shown as blue circles on the map.

Suppose SST can be used as a proxy of turbulent kinetic energy, which could govern the short-term variability of phytoplankton biomass. In that case, the pattern described above is consistent with the one described by Kim et al. [8]. These authors examined the time series of chlorophyll concentration data recorded in situ. They found that Carlini (northern zone) showed the lowest variability in summer, while Rothera and Palmer (southern zone) showed the most significant fluctuations, which is consistent with our results (Tables 1 and 3 and Figure 5). Due to the complex surface (10-20 m) oceanographic structure, the WAP exhibits a marked spatio-temporal variability [72]. This pattern is consistent with the idea of Kim et al. [8], who proposed that local drivers play a central role in the spatio-temporal variability of the WAP, which is the largest of the entire continent according to King [6].

Clem et al. [78] pointed out that when SAM attains high values in the summer, cooling conditions occur in the WAP, consistent with our results (Table 7). However, these authors pointed out that the relationship between SAM and temperatures across the entire peninsula during the summer was weak and non-significant. Kim et al. [7] also reported a low correlation $(r<0.25)$ under conditions of high SAM values.

Although some studies have reported that the total transport of the Antarctic Circumpolar Current may be strongly related to SAM and ENSO, Koening et al. [91] pointed out that such relationships are intermittent and vary with the season of the year. Such relationships can also respond to other non-seasonal drivers [63]. Thus, the Antarctic Circumpolar 
Current does not respond homogeneously along its entire trajectory; consequently, some regions differ in their Antarctic Circumpolar Current flow characteristics, such as the WAP and the Drake Strait.

The understanding of regional climatic variations in the WAP, and their relations with SAM and ENSO, is a hot topic. Although Fogt et al. [79] pointed out almost a decade ago that much work remained to be done in this regard, this statement still holds today [76] for the following reasons. First, the indices depend on external factors (such as the relation between SAM and the atmospheric ozone in the area) that introduce long-term variability. Second, there is significant local variability across the WAP.

One of the key aspects addressed in this work was the description of how and under what conditions an atmospheric phenomenon occurring at lower latitudes close to the equator influences the SST at higher latitudes, such as that of the WAP. The El Niño phenomenon is a complex mixture of environmental responses to the variability of a pressure center that affects wind direction and intensity in the equator. This pressure center is commonly over Asia, giving rise to Walker's cell. The pressure center oscillates along the equator, so it can move to the middle of the Pacific Ocean, creating an anomalous Walker's cell and weakening the winds coming from America to Asia. Occasionally, the pressure center may settle in America, causing a strong El Niño event.

Considering the above, a strong El Niño event causes marked environmental signs, such as positive temperature anomalies and negative nutrient and chlorophyll anomalies, which are distributed along the American coast, minimizing the effects of the California Current (in the northern hemisphere) and the Humboldt Current (in the southern hemisphere). The stronger the event, the higher the latitudes to which positive temperature anomalies can reach. In the case of the WAP, it would have to break or affect the Antarctic Circumpolar Current, which dominates the Drake Strait, in addition to overcoming the Humboldt Current.

For the above and to be able to discern the potential teleconnections between ENSO events and SST in the WAP, we looked for the simplest index representing the variations in the position of the pressure center located in the equator. Analyzing the candidate indices, the following ENSO indices can be mentioned:

1. The SOI [40] is an index based on atmospheric pressure at sea level in Tahiti and Darwin, with a time series since January 1876.

2. The Oceanic Niño Index (ONI; El Niño 3-4) is listed as an index based on sea-surface temperature in the region 3-4 in the equator [92] and has been calculated since 1950. One of the main weaknesses of this index is that it is calculated based on the Extended Reconstructed Sea-Surface Temperature (ERSST).

3. The Multivariate ENSO Index (MEI) [93] combines oceanic and atmospheric variables using an orthogonal empirical function (OEF), encompassing the time period from 1979 to date.

The ONI is based on sea temperature; thus, if we use it, we would be attempting to associate equatorial SST and WAP SST. In other words, we would be seeking to associate two oceanographic responses at two different latitudes. One of the main weakness of this index lies in that it is calculated based on the Extended Reconstructed Sea-Surface Temperature (ERSST) [93]. To note, given the resolution used in the ERSST (2 degrees), these can mask many signals, mostly local. If we seek to detect strong ENSO events, we should use this approach in zone 1-2.

On the other hand, the MEI combines other oceanographic variables evaluated in the equator on a bimonthly basis. Therefore, increasing the number of parameters for calculation with a variability typical of the equator, this may mask the relationships of this index with the SST at high latitudes.

Although this work does not attempt to identify the best index for representing ENSO events and their potential effects at high latitudes of the southern hemisphere, we believe the SOI may be a suitable proxy for ENSO to explore the possible effects on climate variability at these latitudes, based mainly on the length of the time series it covers, coupled 
with the simplicity of its approximation in terms of the calculation variables representing atmospheric variability.

It is important to mention that in such studies conducted at latitudes other than the equatorial Pacific, the full implications of the teleconnections involved in the event remain to be fully determined.

Some methodological aspects deserve further consideration, such as the interpretation and conceptualization of climate indices. There are several ENSO indices, including the El Niño 3-4, also known as the Oceanic Niño Index (ONI) [75,78,79,81-83,94]; the SOI ([79] and this work); and the Multivariate ENSO Index (MEI) [8]). A major confounding factor is that negative SOI values indicate ENSO conditions, with more negative values indicating stronger events; in contrast, positive MEI values indicate an ENSO event and should be interpreted in the opposite way relative to the SOI. Another methodological aspect that deserves consideration is the mathematical approach used to identify the relation between climate variability and climate indices (SAM and ENSO).

These approaches range from linear correlations [79] to EOF [80,95]. Fogt et al. [79] concluded that the mathematical methods used do not always provide a clear description of teleconnections. For instance, correlation coefficients do not provide information on the magnitude of each event and can be influenced by extreme values. The same authors stress that the correlation between ENSO and SAM is non-stationary and relatively weak, suggesting that ENSO and SAM vary independently from each other. Hence, most studies on this topic probably did not include strong ENSO events and only examined low- to medium-intensity events, yielding unclear associations in many cases.

Many authors have used a combination of approaches to identify correlations between climate indices and environmental variables. These include coefficients of determination and correlation [82], correlations and regressions [96], correlations and PCA [83], correlations and EOF [81], and independence tests based on the chi-square distribution [79]. Since each climate variable and index can exhibit short-, medium-, and long-term variations, the time series to be analyzed should be sufficiently long to allow detecting those relations. When only short time series are available (as in this study), the combination of various approaches can help identify correlations between SAM and SOI indices and SST and describe them in a comprehensive spatio-temporal manner.

It is worth noting that, although many works in the WAP mention a clear relationship between the SST variability and SAM and any other El Niño index, most works did not intend to determine the statistical significance of their analyses. Thus, we believe the statistical significance of these findings should be determined in order to detect associations based on a solid support.

Another methodological aspect worth considering is the sea temperature data used for analysis. Temperature data can be based on the ERSST or derived from satellite observations (as in this study). Different versions of the ERSST data have been used (version 3 by Fogt et al. [79] and Yeo and Kim [82]; version 4 by Clem et al. [78] and Kim et al. [75]; and a fifth version that is now available [97]). However, all versions of this database have a $2^{\circ}$ spatial resolution. Fogt and Bromwich [83] pointed out that because of how ERSST data are constructed, this coarse resolution seriously limits the scope of the studies based on these data. Jones et al. [76] explained that these limitations are particularly critical in the high southern latitudes due to the precision and temporal consistency of the data (especially considering the scarcity of pre-1979 data), leading to unreliable descriptions. We confirmed this issue when we attempted to use the time series (1854 to date) of version 4 and version 5 ERSST data to describe climate variability in the WAP (data and analyses not shown) and could not discern any spatio-temporal association pattern. The $2^{\circ}$ spatial resolution of these data masks the local variability, which is highly relevant and characteristic of the WAP, as shown by our results. Although new, improved versions of these data are currently available (with improved quality flags), they may not be entirely suitable to describe climate variability in the WAP, as their spatial resolution has not increased. 
The NOAA Optimum Interpolation (OI) SST v2 data have been used in order to address this limitation [72]. However, the $1^{\circ}$ spatial resolution of these data is still insufficient and continues obscuring local processes. We used infrared radiometric observations to improve the spatial resolution of the data to $1 \mathrm{~km}$ and better examine local variability. Using data from the AVHRR sensor, this approach yields a time series from 1980 to 2009, when this sensor ceased operating [80,98]. We contemplated including AVHRR data in the multi-sensor $1 \mathrm{~km}$ resolution composites used for this study and thus obtain time series covering from 1981 to 2020. However, we were unable to obtain $1 \mathrm{~km}$ resolution AVHRR data. Therefore, we decided to use $4 \mathrm{~km}$ resolution AVHRR scenes between 2000 and 2009, but the resulting series (data not shown) showed no temporal pattern.

Our failure to identify any discernible pattern in the AVHRR time series can be explained by the errors contained in these data. As pointed out by the National Snow \& Ice Data Center (NSIDC [99]), they do not distribute AVHRR data because of the several errors that have been reported. Such errors are described in the $4 \mathrm{~km}$ Pathfinder Version 5 User's Guide [100], which states that the use of these data, especially at high latitudes and low temperatures, requires the application of quality indicators and should include a "reality check" to identify and discard anomalous SST values. This caveat does not hold for mid and equatorial latitudes, where values below $0{ }^{\circ} \mathrm{C}$ can be readily detected as anomalous data. This is an important element to consider when using AVHRR data from the NASA or NOAA repositories of global coverage. Nevertheless, we can still explore the possibility of using AVHRR Polar Pathfinder (APP) and Extended AVHRR Polar Pathfinder (APP-x) to describe climate variability in the Antarctic and the Arctic.

Currently, and seeking to have continuous SST readings, the non-linear SST (NLSST) algorithm of Walton et al. [24] has been modified. It is necessary, however, to pay attention to the pre-processing currently applied to SST images. The AVHRR Pathfinder SST and the first versions of MODIS SST, particularly the R2010 reprocessing (or 5 and 4 collections), were previously considered monthly sets of coefficients for two different atmospheric regimes based on spectral brightness temperature difference [25,101]. Given the marked latitudinal variability of SST, it was found that this approximation is unsuitable for high latitudes; consequently, from the R2014 reprocessing monthly coefficients were derived for different atmospheric regions based on latitudinal belts. This is when the calculation of SST in the polar regions started to raise attention. More specifically, the R2014 and R2016 reprocessing were based on six latitude belts at 20-degree intervals from the equator to $40^{\circ}$. A broad band was used for each of the poles, encompassing from $40^{\circ}$ to the pole in each hemisphere. The works by [102-104] para el Arctic zone show that the complexity of the polar atmosphere and all the atmospheric components may play a major role, as in the case of the effect of ice crystals on the orientation of aerosols. For the above, Kilpatrick et al. [105] and Jia and Minnett [106] state that R2019 (at least for MODIS) includes an additional band stretching from $60^{\circ} \mathrm{N}$ to the pole, which better represents the Arctic region. Although there are no published works considering a similar band for the Antarctic region $\left(60^{\circ} \mathrm{S}\right.$ to the pole), we believe this approach will soon be applied to the Antarctic and other sensors capable of recording SST, given the relevance of understanding climatic variability based on SST at high latitudes.

One of the challenges imposed by the WAP is the availability of valid data. Two contrasting conditions occur in these latitudes. On the one hand, circumpolar sensors make several passes per day, but atmospheric conditions do not allow collecting sufficient high-quality $1 \mathrm{~km}$ resolution daily data. These conditions are evident even when daily $4 \mathrm{~km}$ (Global Area Cover, GLO) composites from a single sensor are used. The image resolution is sometimes reduced to fill the gap to, for example, $6.5 \mathrm{~km}$ [80]. Another common practice consists of performing seasonal studies, compiling austral summer (December-JanuaryFebruary) composites [78,83,94].

The multi-sensor approach in our study, taking into account the extra quality flags that detect anomalous data, provided us with high-quality $1 \mathrm{~km}$ resolution data, which revealed local differences in the WAP and provided reliable information at least monthly. 
The best data for these purposes might be those recorded by the research stations located in the WAP. However, this would demand deploying enormous efforts, such as those carried out at the Palmer station [107] across the full range of the WAP.

\section{Conclusions}

The WAP is one of the most easily accessible regions of the Antarctic and exhibits an evident spatio-temporal variability. Climate variability, as assessed in terms of SST, shows a significant cycle of one warm year followed by four or five cold years. Warm episodes occur more regularly than cold ones. During warm episodes, warm waters $\left(\mathrm{SST}>0{ }^{\circ} \mathrm{C}\right)$ reach the WAP coast, while warm waters remain far from the shore during cold episodes. This sequence of warm and cold episodes can be described as calming waves splashing onto the beach and affecting the trophic structure in the region.

The inflow of warm waters into the WAP may be related to the strengthening or weakening of the Antarctic Circumpolar Current. The lukewarm water reaching the WAP every four to five years could be explained by the intrusion of the South Polar Front Zone and the displacement of the Antarctic Zone during warm episodes. However, the mechanisms driving this intrusion are still not fully understood and have garnered growing attention in the zone.

The WAP can be spatially split into two large zones that exhibit a distinctive spatiotemporal variability. These zones represent two distinct ecoregions of the Scotia Sea province of the Southern Ocean realm: the northern zone (defined by the Carlini station), which belongs to the South Shetland Islands ecoregion, and the southern zone (represented by the Palmer and Rothera stations), in the Antarctic Peninsula ecoregion. The Gerlache station is situated at the boundary between these two ecoregions but under greater influence from the South Shetland Islands ecoregion.

The Antarctic Circumpolar Current is driven primarily by wind throughout its trajectory; thus, a possible teleconnection of Antarctic Circumpolar Current and ENSO with SAM in the WAP was explored. Our data showed that the main driver is SAM, with ENSO playing a secondary role. However, it is essential that climate models for the WAP adequately simulate temperature trends and their forcing by SAM or ENSO. Aspects to consider in this regard include the reported association between SAM and atmospheric ozone concentration; if the latter is expected to vary over the following 20 years, ensuing changes in SAM are to be expected. Extreme ENSO events have not been studied so far; instead, studies have focused on the El Niño-La Niña cycle. Thus, it is necessary to look for such strong events as they can simplify the approaches needed to examine the influence of ENSO events on climate variability.

Thus, understanding the regional variations in SST and their relation with SAM and ENSO when describing climate variability in the WAP is a hot topic that still demands considerable efforts to properly account for the complex associations involved. Some critical methodological issues that should be considered range from selecting a suitable ENSO index to using adequate SST data. Our study adopted a multi-sensor approach that allowed identifying local variations, which previous studies had failed to identify, and provided a clear overview of the complex climate variability stemming from local processes that behave differently across the WAP.

Calculations to derive SST at high latitudes is a hot topic, and many approaches have been used for the Arctic region. Hopefully, these same concepts and approaches will be also applied to the Antarctic Zone.

Author Contributions: Conceptualization, E.S.-d.-Á., M.-L.C.-P., M.-T.S.-F., A.G.-S., A.-L.G., J.-A.A.M., J.L.-C., V.C.-I., A.F.-H., and A.C.-R.; methodology, E.S.-d.-Á., M.-L.C.-P., M.-T.S.-F., and J.-A.A.-M.; software, E.S.-d.-Á. and J.-A.A.-M.; validation, E.S.-d.-Á., J.-A.A.-M., and A.C.-R.; formal analysis, E.S.-d.-Á., M.-L.C.-P., M.-T.S.-F., A.G.-S., A.-L.G., J.-A.A.-M., J.L.-C., V.C.-I., A.F.-H., and A.C.-R.; investigation, E.S.-d.-Á. and M.-L.C.-P.; resources, E.S.-d.-Á.; data curation, E.S.-d.-Á.; writingoriginal draft preparation, E.S.-d.-Á.; writing—review and editing, E.S.-d.-Á., M.-L.C.-P., M.-T.S.-F., A.G.-S., A.-L.G., J.-A.A.-M., J.L.-C., V.C.-I., A.F.-H., and A.C.-R.; visualization, E.S.-d.-Á., M.-L.C.-P., 
M.-T.S.-F., A.G.-S., A.-L.G., J.-A.A.-M., J.L.-C., V.C.-I., A.F.-H., and A.C.-R.; supervision, E.S.-d.Á., M.-L.C.-P., M.-T.S.-F., A.G.-S., A.-L.G., J.-A.A.-M., J.L.-C., V.C.-I., A.F.-H., and A.C.-R.; project administration, E.S.-d.-Á., M.-L.C.-P., A.G.-S., and A.-L.G.; funding acquisition, E.S.-d.-Á., M.-L.C.-P., A.G.-S., and A.-L.G. All authors have read and agreed to the published version of the manuscript.

Funding: This work was supported by the Universidad Autónoma de Baja California, AmeriGEOSS, and the CONACYT's project number CB-2012-01/179753.

Institutional Review Board Statement: Not applicable.

Informed Consent Statement: Not applicable.

Data Availability Statement: Data available on request.

Acknowledgments: We thank the Universidad Autónoma de Baja California, AmeriGEOSS, Dirección General Marítima de Colombia, and the Colombian Antarctic Program. M-L.C-P and A.C-R. are Ph.D. students enrolled in the Doctorate Program on Coastal Oceanography at the Facultad de Ciencias Marinas of Universidad Autónoma de Baja California, Mexico, and are supported by the Mexican Consejo Nacional de Ciencia y Tecnologia through Ph.D. scholarship. María Elena Sánchez-Salazar translated the manuscript into English.

Conflicts of Interest: The authors declare no conflict of interest.

\section{References}

1. Farman, J.C.; Gardiner, B.G.; Shanklin, J.D. Large losses of total ozone in Antarctica reveal seasonal ClOx/NOx interaction. Nat. Cell Biol. 1985, 315, 207-210. [CrossRef]

2. Brook, E.J.; Buizert, C. Antarctic and global climate history viewed from ice cores. Nat. Cell Biol. 2018, 558, 200-208. [CrossRef] [PubMed]

3. Moore, J.K.; Fu, W.; Primeau, F.; Britten, G.L.; Lindsay, K.; Long, M.; Doney, S.C.; Mahowald, N.; Hoffman, F.; Randerson, J.T. Sustained climate warming drives declining marine biological productivity. Science 2018, 359, 1139-1143. [CrossRef] [PubMed]

4. Bornman, J.F.; Barnes, P.W.; Robson, T.M.; Robinson, S.A.; Jansen, M.A.K.; Ballaré, C.L.; Flint, S.D. Linkages between stratospheric ozone, UV radiation and climate change and their implications for terrestrial ecosystems. Photochem. Photobiol. Sci. 2019, 18, 681-716. [CrossRef] [PubMed]

5. COMNAP. COMNAP Antarctic Station Catalogue. 2017. Available online: https://www.comnap.aq/Members/Shared\%20 Documents/COMNAP_Antarctic_Station_Catalogue.pdf (accessed on 20 November 2020).

6. King, J.C. Recent climate variability in the vicinity of the Antarctic Peninsula. Int. J. Clim. 1994, 14, 357-369. [CrossRef]

7. Saba, G.K.; Fraser, W.R.; Saba, V.S.; Iannuzzi, R.A.; Coleman, K.E.; Doney, S.C.; Ducklow, H.W.; Martinson, D.G.; Miles, T.N.; Patterson-Fraser, D.L.; et al. Winter and spring controls on the summer food web of the coastal West Antarctic Peninsula. Nat. Commun. 2014, 5, 4318. [CrossRef]

8. Kim, H.; Ducklow, H.W.; Abele, D.; Ruiz Barlett, E.M.; Buma, A.G.; Meredith, M.P.; Rozema, P.D.; Schofield, O.M.; Venables, H.J.; Schloss, I.R. Inter-decadal variability of phytoplankton biomass along the coastal West Antarctic Peninsula. Philos. Trans. R. Soc. A 2018, 376, 20170174. [CrossRef]

9. Montes-Hugo, M.; Doney, S.C.; Ducklow, H.W.; Fraser, W.R.; Martinson, D.G.; Stammerjohn, S.E.; Schofield, O. Recent Changes in Phytoplankton Communities Associated with Rapid Regional Climate Change Along the Western Antarctic Peninsula. Science 2009, 323, 1470-1473. [CrossRef]

10. Whitehouse, M.; Meredith, M.; Rothery, P.; Atkinson, A.; Ward, P.; Korb, R. Rapid warming of the ocean around South Georgia, Southern Ocean, during the 20th century: Forcings, characteristics and implications for lower trophic levels. Deep. Sea Res. Part I Oceanogr. Res. Pap. 2008, 55, 1218-1228. [CrossRef]

11. Cañon-Páez, M.L.; Santamaría-del-Ángel, E.; Lopez Calderón, J.M.; González-Silveira, A.G.; Camacho-Ibar, V.F.; Fran-co-Herrera, A. Changes in Community Structure Based on the Reconstruction of Type Spectra of the Specific Absorption Coefficient of Phytoplankton in the Gerlache Strait. (in preparation). March 2021.

12. Vaughan, D.G.; Marshall, G.J.; Connolley, W.M.; King, J.C.; Mulvaney, R. Climate change: Devil in the Detail. Science 2001, 293, 1777-1779. [CrossRef] [PubMed]

13. Marshall, G.J.; Lagun, V.; Lachlan-Cope, T.A. Changes in Antarctic Peninsula tropospheric temperatures from 1956 to 1999: A synthesis of observations and reanalysis data. Int. J. Clim. 2002, 22, 291-310. [CrossRef]

14. Vaughan, D.G.; Marshall, G.J.; Connolley, W.M.; Parkinson, C.; Mulvaney, R.; Hodgson, D.A.; King, J.C.; Pudsey, C.J.; Turner, J. Recent Rapid Regional Climate Warming on the Antarctic Peninsula. Clim. Chang. 2003, 60, 243-274. [CrossRef]

15. Meredith, M.P.; King, J.C. Rapid climate change in the ocean west of the Antarctic Peninsula during the second half of the 20th century. Geophys. Res. Lett. 2005, 32, 19. [CrossRef]

16. Smith, R.C.; Stammerjohn, S.E.; Baker, K.S. Surface air temperature variations in the Western Antarctic Peninsula region, in Foundations for Ecological Research West of the Antarctic Peninsula. Antarct. Res. Ser. 1996, 70, 105-121. 
17. Turner, J.; Colwell, S.R.; Marshall, G.J.; Lachlan-Cope, T.A.; Carleton, A.M.; Jones, P.D.; Lagun, V.; Reid, P.A.; Iagovkina, S. Antarctic climate change during the last 50 years. Int. J. Clim. 2005, 25, 279-294. [CrossRef]

18. Clarke, A.; Griffiths, H.J.; Barnes, D.K.A.; Meredith, M.P.; Grant, S.M. Spatial variation in seabed temperatures in the Southern Ocean: Implications for benthic ecology and biogeography. J. Geophys. Res. Space Phys. 2009, 114, 03003. [CrossRef]

19. Moffat, C.; Meredith, M. Shelf-ocean exchange and hydrography west of the Antarctic Peninsula: A review. Philos. Trans. R. Soc. A Math. Phys. Eng. Sci. 2018, 376, 20170164. [CrossRef] [PubMed]

20. Vazquez, J.; Li, X. (Eds.) Sea Surface Temperature Retrievals from Remote Sensing. Remote Sens. 2018, 340. [CrossRef]

21. Santamaría-del-Angel, E.; Soto, I.; Millán-Nuñez, R.; González-Silvera, A.; Wolny, J.; Cerdeira-Estrada, S.; Cajal-Medrano, R.; Muller-Karger, F.; Cannizzaro, J.; Padilla-Rosas, Y.X.S.; et al. Anthropocentric bias in management policies. Are we efficiently monitoring our ecosystem? In Coastal Ecosystems: Experiences and Recommendations for Environmental Monitoring Programs; Sebastiá-Frasquet, M.T., Ed.; Nova Science Publishers: New York, NY, USA, 2015; Chapter 1; pp. 1-12. ISBN 978-1-63482-189-6i.

22. Palmer Long-Term Ecological Research. Available online: https://pal.lternet.edu/ (accessed on 4 August 2020).

23. Ocean Color Data. Available online: https:/ / oceancolor.gsfc.nasa.gov/ (accessed on 4 August 2020).

24. Walton, C.C.; Pichel, W.G.; Sapper, J.F.; May, D.A. The development and operational application of nonlinear algorithms for the measurement of sea surface temperatures with the NOAA polar-orbiting environmental satellites. J. Geophys. Res. Space Phys. 1998, 103, 27999-28012. [CrossRef]

25. Kilpatrick, K.; Podestá, G.; Walsh, S.; Williams, E.; Halliwell, V.; Szczodrak, M.; Brown, O.; Minnett, P.; Evans, R. A decade of sea surface temperature from MODIS. Remote Sens. Environ. 2015, 165, 27-41. [CrossRef]

26. Kahru, M.; Di Lorenzo, E.; Manzano-Sarabia, M.; Mitchell, B.G. Spatial and temporal statistics of sea surface temperature and chlorophyll fronts in the California Current. J. Plankton Res. 2012, 34, 749-760. [CrossRef]

27. Kahru, M.; Kudela, R.M.; Anderson, C.R.; Mitchell, B.G. Optimized Merger of Ocean Chlorophyll Algorithms of MODIS-Aqua and VIIRS. IEEE Geosci. Remote Sens. Lett. 2015, 12, 2282-2285. [CrossRef]

28. Wim Software. Available online: https://www.wimsoft.com (accessed on 20 November 2020).

29. Santamaría-del-Ángel, E.; Sebastia-Frasquet, M.-T.; González-Silvera, A.; Aguilar-Maldonado, J.; Mercado-Santana, A.; HerreraCarmona, J.C. Uso potencial de las anomalías estandarizadas en la interpretación de fenómenos oceanográficos globales a escalas locales. Chapter Procesos y ciclos en la costa; In Tópicos de Agenda para la Sostenibilidad de Costas y Mares Mexicanos; Rivera-Arriaga, E., Sánchez-Gil, P., Gutiérrez, J., Eds.; Universidad Autónoma de Campeche: Campeche, Mexico, 2019; pp. 193-212, 334, ISBN 978-607-8444-57-1.

30. Chen, S.; Wu, R. Impacts of winter NPO on subsequent winter ENSO: Sensitivity to the definition of NPO index. Clim. Dyn. 2017, 50, 375-389. [CrossRef]

31. Morales-Acuña, E.; Torres, C.R.; Delgadillo-Hinojosa, F.; Linero-Cueto, J.R.; Santamaría-Del-Ángel, E.; Castro, R. The Baja California Peninsula, a Significant Source of Dust in Northwest Mexico. Atmosphere 2019, 10, 582. [CrossRef]

32. Di Matteo, S.; Viall, N.M.; Kepko, L. Power Spectral Density Background Estimate and Signal Detection via the Multitaper Method. J. Geophys. Res. Space Phys. 2021, 126, e2020JA028748. [CrossRef]

33. Schonlau, M. The Clustergram: A Graph for Visualizing Hierarchical and Nonhierarchical Cluster Analyses. Stata J. 2002, 2, 391-402. [CrossRef]

34. Jamshidian, M.; Jalal, S. Tests of Homoscedasticity, Normality, and Missing Completely at Random for Incomplete Multivariate Data. Psychometrika 2010, 75, 649-674. [CrossRef]

35. Liang, J.; Pan, W.S.; Yang, Z.H. Characterization-based Q-Q plots for testing multinormality. Stat. Probabil. Lett. 2004, 70, 183-190. [CrossRef]

36. Bureau of Meteorology. Available online: http://www.bom.gov.au/climate/current/soihtm1.shtml (accessed on 4 August 2020).

37. Marshall, G.J. Trends in the Southern Annular Mode from observations and reanalyses. J. Clim. 2003, 16, 4134-4143. [CrossRef]

38. Climate Date Guide. Available online: https://climatedataguide.ucar.edu/climate-data/marshall-southern-annular-mode-samindex-station-based (accessed on 4 August 2020).

39. SAM Index. Available online: https://legacy.bas.ac.uk/met/gjma/sam.html (accessed on 8 August 2020).

40. Bureau Meteorology. Available online: http://www.bom.gov.au/climate/enso/history/ln-2010-12/SAM-what.shtml (accessed on 12 August 2020).

41. Santamaría-del-Angel, E.; Millán-Núñez, R.; González-Silvera, A.; Cajal-Medrano, R. A comparison of Chl a concentrations estimated in situ and $\mathrm{Chl}$ a concentrations determined via remote sensing: A statistical examination of the match-up approach. In Handbook of Satellite Remote Sensing Image Interpretation: Applications for Marine Living Resources Conservation and Management; Morales, J., Stuart, V., Platt, T., Sathyendranath, S.J., Eds.; EU PRESPO and IOCCG: Dartmouth, NS, Canada, 2011; Chapter 17; pp. 241-259. Available online: https:/ / www.ioccg.org/handbook/casestudy17_angel_etal.pdf (accessed on 2 December 2020).

42. Perdices, M. Null Hypothesis Significance Testing, p-values, Effects Sizes and Confidence Intervals. Brain Impair. 2018, 19, 70-80. [CrossRef]

43. Mu, Y.; Liu, X.; Wang, L. A Pearson's correlation coefficient based decision tree and its parallel implementation. Inf. Sci. 2018, 435, 40-58. [CrossRef]

44. Farnsworth, D.L.; Triola, M.F. Elementary Statistics. Technometrics 1990, 32, 456. [CrossRef]

45. Kokoska, S.; Nevison, C. Critical values for Spearman's rank correlation coefficient. In Statistical Tables and Formulae; Springer: New York, NY, USA, 1989. [CrossRef] 
46. Santamaría-del-Ángel, E.; González-Silvera, A.; Millán-Núñez, R.; Callejas-Jiménez, M.E.; Cajal-Medrano, R. Determining dynamic biogeographic regions using remote sensing data. In Handbook of Satellite Remote Sensing Image Interpretation: Applications for Marine Living Resources Conservation and Management; Morales, J., Stuart, V., Platt, T., Sathyendranath, S.J., Eds.; EU PRESPO and IOCCG: Dartmouth, NS, Canada, 2011; Chapter 19; pp. 273-293. Available online: https://www.ioccg.org/handbook/ casestudy19_angel_etal.pdf (accessed on 2 December 2020).

47. Kaiser, H.F. The varimax criterion for analytic rotation in factor analysis. Psychometrika 1958, 23, 187-200. [CrossRef]

48. Yeomans, K.A.; Golder, P.A. The Guttman-Kaiser Criterion as a Predictor of the Number of Common Factors. Amer. Statist. 1982, 31, 221. [CrossRef]

49. Ferré, L. Selection of components in principal component analysis: A comparison of methods. Comput. Stat. Data Anal. 1995, 19, 669-682. [CrossRef]

50. Kanyongo, G.Y. Determining the correct number of components to extract from a principal components analysis: A Monte Carlo study of the accuracy of the scree plot. J Mod. Appl. Stat. Methods 2005, 4, 120-133. [CrossRef]

51. Schreiber, J.B. Issues and recommendations for exploratory factor analysis and principal component analysis. Res. Soc. Adm. Pharm. 2020. [CrossRef] [PubMed]

52. Navarro Fierro, R. Introducción a la bioestadística: Análisis de variables binarias; McGRAW-Hill: Ciudad de Mexico, Mexico, 1988; 170p, ISBN 968-422-387-0.

53. Santamaría-Del-Angel, E.; Alvarez-Borrego, S.; Muller-Karger, F.E. The 1982-1984 El Niño in the Gulf of California as seen in coastal zone color scanner imagery. J. Geophys. Res. Space Phys. 1994, 99, 7423-7431. [CrossRef]

54. Turner, J.; Marshall, G.J.; Clem, K.; Colwell, S.; Phillips, T.; Lu, H. Antarctic temperature variability and change from station data. Int. J. Clim. 2020, 40, 2986-3007. [CrossRef]

55. Ducklow, H.W.; Baker, K.; Martinson, D.G.; Quetin, L.B.; Ross, R.M.; Smith, R.C.; Stammerjohn, S.E.; Vernet, M.; Fraser, W. Marine pelagic ecosystems: The West Antarctic Peninsula. Philos. Trans. R. Soc. B Biol. Sci. 2006, 362, 67-94. [CrossRef] [PubMed]

56. Atkinson, A.; Siegel, V.; Pakhomov, E.; Rothery, P. Long-term decline in krill stock and increase in salps within the Southern Ocean. Nat. Cell Biol. 2004, 432, 100-103. [CrossRef] [PubMed]

57. Suprenand, P.M.; Ainsworth, C.H. Trophodynamic effects of climate change-induced alterations to primary production along the western Antarctic Peninsula. Mar. Ecol. Prog. Ser. 2017, 569, 37-54. [CrossRef]

58. Clarke, A.; Murphy, E.J.; Meredith, M.P.; King, J.C.; Peck, L.S.; Barnes, D.K.A.; Smith, R.C. Climate change and the marine ecosystem of the western Antarctic Peninsula. Philos. Trans. R. Soc. B Biol. Sci. 2006, 362, 149-166. [CrossRef]

59. White, W.B.; Peterson, R.G. An Antarctic circumpolar wave in surface pressure, wind, temperature and sea-ice extent. Nature 1996, 380, 699-702. [CrossRef]

60. Donohue, K.A.; Tracey, K.L.; Watts, D.R.; Chidichimo, M.P.; Chereskin, T.K. Mean Antarctic Circumpolar Current transport measured in Drake Passage. Geophys. Res. Lett. 2016, 43, 11-760. [CrossRef]

61. Constantin, A.; Johnson, R.S. An Exact, Steady, Purely Azimuthal Flow as a Model for the Antarctic Circumpolar Current. J. Phys. Oceanogr. 2016, 46, 3585-3594. [CrossRef]

62. Tarakanov, R.Y.; Gritsenko, A.M. Jets of the Antarctic Circumpolar Current in the Drake Passage Based on Hydrographic Section Data. Oceanology 2018, 58, 503-516. [CrossRef]

63. Giglio, D.; Johnson, G.C. Subantarctic and Polar Fronts of the Antarctic Circumpolar Current and Southern Ocean Heat and Freshwater Content Variability: A View from Argo. J. Phys. Oceanogr. 2016, 46, 749-768. [CrossRef]

64. Haziot, S.V.; Marynets, K. Applying the stereographic projection to modeling of the flow of the Antarctic Circumpolar Current. Oceanography 2018, 31, 68-75. [CrossRef]

65. Quirchmayr, R. A steady, purely azimuthal flow model for the Antarctic Circumpolar Current. Mon. Math. 2017, 187, 565-572. [CrossRef]

66. Marynets, K. The Antarctic Circumpolar Current as a shallow-water asymptotic solution of Euler's equation in spherical coordinates. Deep. Sea Res. Part II Top. Stud. Oceanogr. 2019, 160, 58-62. [CrossRef]

67. Haziot, S.V. Study of an elliptic partial differential equation modelling the Antarctic Circumpolar Current. Discret. Contin. Dyn. Syst. A 2019, 39, 4415-4427. [CrossRef]

68. Koshlyakov, M.N.; Savchenko, D.S.; Tarakanov, R.Y. Energy Exchange between Jets of the Antarctic Circumpolar Current and Synoptic Eddies in the Drake Passage and Scotia Sea. Oceanology 2018, 58, 329-339. [CrossRef]

69. Song, H.; Long, M.C.; Gaube, P.; Frenger, I.; Marshall, J.; McGillicuddy, D.J., Jr. Seasonal Variation in the Correlation Between Anomalies of Sea Level and Chlorophyll in the Antarctic Circumpolar Current. Geophys. Res. Lett. 2018, 45, 5011-5019. [CrossRef]

70. Balwada, D.; Speer, K.G.; LaCasce, J.H.; Owens, W.B.; Marshall, J.C.; Ferrari, R. Circulation and Stirring in the Southeast Pacific Ocean and the Scotia Sea Sectors of the Antarctic Circumpolar Current. J. Phys. Oceanogr. 2016, 46, 2005-2027. [CrossRef]

71. King, J.C.; Turner, J.; Marshall, G.J.; Connolley, W.M.; Lachlan-Cope, T.A.; King, J.C.; Turner, J.; Marshall, G.J.; Connolley, W.M.; Lachlan-Cope, T.A. Antarctic Peninsula climate variability and its causes as revealed by analysis of instrumental records. In Antarctic Peninsula Climate Variability: Historical and Paleoenvironmental Perspectives; American Geophysical Union: Washington, DC, USA, 2003; Volume 79, pp. 17-30. [CrossRef]

72. Barnes, D.K.; Fuentes, V.; Clarke, A.; Schloss, I.R.; Wallace, M.I. Spatial and temporal variation in shallow seawater temperatures around Antarctica. Deep. Sea Res. Part II Top. Stud. Oceanogr. 2006, 53, 853-865. [CrossRef] 
73. Thompson, A.F.; Stewart, A.L.; Spence, P.; Heywood, K.J. The Antarctic Slope Current in a Changing Climate. Rev. Geophys. 2018, 56, 741-770. [CrossRef]

74. Kim, Y.S.; Orsi, A.H. On the Variability of Antarctic Circumpolar Current Fronts Inferred from 1992-2011 Altimetry. J. Phys. Oceanogr. 2014, 44, 3054-3071. [CrossRef]

75. Kim, H.; Doney, S.C.; Iannuzzi, R.A.; Meredith, M.P.; Martinson, D.G.; Ducklow, H.W. Climate forcing for dynamics of dissolved inorganic nutrients at Palmer Station, Antarctica: An interdecadal (1993-2013) analysis. J. Geophys. Res. Biogeosciences 2016, 121, 2369-2389. [CrossRef]

76. Jones, M.E.; Bromwich, D.H.; Nicolas, J.P.; Carrasco, J.; Plavcová, E.; Zou, X.; Wang, S.-H. Sixty Years of Widespread Warming in the Southern Middle and High Latitudes (1957-2016). J. Clim. 2019, 32, 6875-6898. [CrossRef]

77. Stammerjohn, S.E.; Martinson, D.G.; Smith, R.C.; Yuan, X.; Rind, D. Trends in Antarctic annual sea ice retreat and advance and their relation to El Niño-Southern Oscillation and Southern Annular Mode variability. J. Geophys. Res. Space Phys. 2008, $113,4603$. [CrossRef]

78. Clem, K.R.; Renwick, J.A.; McGregor, J.; Fogt, R.L. The relative influence of ENSO and SAM on Antarctic Peninsula climate. J. Geophys. Res. Atmos. 2016, 121, 9324-9341. [CrossRef]

79. Fogt, R.L.; Bromwich, D.H.; Hines, K.M. Understanding the SAM influence on the South Pacific ENSO teleconnection. Clim. Dyn. 2011, 36, 1555-1576. [CrossRef]

80. Kwok, R.; Comiso, J.C. Spatial patterns of variability in Antarctic surface temperature: Connections to the Southern Hemisphere Annular Mode and the Southern Oscillation. Geophys. Res. Lett. 2002, 29, 50-51. [CrossRef]

81. Pezza, A.B.; Rashid, H.A.; Simmonds, I. Climate links and recent extremes in antarctic sea ice, high-latitude cyclones, Southern Annular Mode and ENSO. Clim. Dyn. 2012, 38, 57-73. [CrossRef]

82. Yeo, S.-R.; Kim, K.-Y. Decadal changes in the Southern Hemisphere sea surface temperature in association with El Niño-Southern Oscillation and Southern Annular Mode. Clim. Dyn. 2015, 45, 3227-3242. [CrossRef]

83. Fogt, R.L.; Bromwich, D.H. Decadal Variability of the ENSO Teleconnection to the High-Latitude South Pacific Governed by Coupling with the Southern Annular Mode. J. Clim. 2006, 19, 979-997. [CrossRef]

84. Lachlan-Cope, T.; Connolley, W. Teleconnections between the tropical Pacific and the Amundsen-Bellinghausens Sea: Role of the El Niño/Southern Oscillation. J. Geophys. Res. Space Phys. 2006, 111, 111. [CrossRef]

85. Yiu, Y.Y.S.; Maycock, A.C. The linearity of the El Niño teleconnection to the Amundsen Sea region. Q. J. R. Meteorol. Soc. 2020, 146, 1169-1183. [CrossRef]

86. Sexton, D.M.H. The effect of stratospheric ozone depletion on the phase of the Antarctic Oscillation. Geophys. Res. Lett. 2001, 28, 3697-3700. [CrossRef]

87. Gillett, N.P.; Allen, M.R.; Williams, K.D. Modelling the atmospheric response to doubled CO2 and depleted stratospheric ozone using a stratosphere-resolving coupled GCM. Q. J. R. Meteorol. Soc. 2003, 129, 947-966. [CrossRef]

88. Chipperfield, M.P.; Dhomse, S.S.; Feng, W.; McKenzie, R.L.; Velders, G.; Pyle, J.A. Quantifying the ozone and ultraviolet benefits already achieved by the Montreal Protocol. Nat. Commun. 2015, 6, 7233. [CrossRef] [PubMed]

89. Spalding, M.D.; Fox, H.E.; Allen, G.R.; Davidson, N.; Ferdaña, Z.A.; Finlayson, M.; Halpern, B.S.; Jorge, M.A.; Lombana, A.; Lourie, S.A.; et al. Marine Ecoregions of the World: A Bioregionalization of Coastal and Shelf Areas. Bioscience 2007, 57, 573-583. [CrossRef]

90. Nature Conservancy. Available online: https://geospatial.tnc.org/datasets/ed2be4cf8b7a451f84fd093c2e7660e3_0 (accessed on 4 August 2020).

91. Koenig, Z.; Provost, C.; Ferrari, R.; Sennéchael, N.; Park, Y.-H. Anatomy of the Antarctic Circumpolar Current volume transports through Drake Passage. J. Geophys. Res. Oceans 2016, 121, 2572-2595. [CrossRef]

92. National Weather Service Climate Prediction Center. Available online: https://origin.cpc.ncep.noaa.gov/products/analysis_ monitoring/ensostuff/ONI_v5.php (accessed on 14 January 2021).

93. Physical Sciences Laboratory. Available online: https://psl.noaa.gov/enso/mei (accessed on 14 January 2021).

94. Welhouse, L.J.; Lazzara, M.A.; Keller, L.M.; Tripoli, G.J.; Hitchman, M.H. Composite analysis of the effects of ENSO events on Antarctica. J. Clim. 2016, 29, 1797-1808. [CrossRef]

95. Yu, J.Y.; Paek, H.; Saltzman, E.S.; Lee, T. The early 1990s change in ENSO-PSA-SAM relationships and its impact on Southern Hemisphere climate. J. Clim. 2015, 28, 9393-9408. [CrossRef]

96. Scott, R.C.; Nicolas, J.P.; Bromwich, D.H.; Norris, J.R.; Lubin, D. Meteorological Drivers and Large-Scale Climate Forcing of West Antarctic Surface Melt. J. Clim. 2019, 32, 665-684. [CrossRef]

97. National Oceanic and Atmospheric Administration. Available online: https://www.ncdc.noaa.gov/data-access/marineoceandata/extended-reconstructed-sea-surface-temperature-ersst-v5 (accessed on 7 August 2020).

98. Ding, Q.; Steig, E.J. Temperature Change on the Antarctic Peninsula Linked to the Tropical Pacific. J. Clim. 2013, 26, 7570-7585. [CrossRef]

99. National Snow \& Ice Data Center. Available online: Nsidc.org/data/avhrr (accessed on 9 August 2020).

100. National Oceanic and Atmospheric Administration. Available online: https://www.nodc.noaa.gov/sog/pathfinder4km/ userguide.html (accessed on 10 August 2020). 
101. Kilpatrick, K.A.; Podestá, G.P.; Evans, R. Overview of the NOAA/NASA advanced very high resolution radiometer Pathfinder algorithm for sea surface temperature and associated matchup database. J. Geophys. Res. Space Phys. 2001, 106, $9179-9197$. [CrossRef]

102. Vincent, R.F.; Marsden, R.F.; Minnett, P.J.; Creber, K.A.M.; Buckley, J.R. Arctic waters and marginal ice zones: A composite Arctic sea surface temperature algorithm using satellite thermal data. J. Geophys. Res. Space Phys. 2008, 113, 04021. [CrossRef]

103. Vincent, R.F.; Marsden, R.F.; Minnett, P.J.; Buckley, J.R. Arctic waters and marginal ice zones: 2. An investigation of arctic atmospheric infrared absorption for advanced very high resolution radiometer sea surface temperature estimates. J. Geophys. Res. Space Phys. 2008, 113, 08044. [CrossRef]

104. Vincent, R. The Case for a Single Channel Composite Arctic Sea Surface Temperature Algorithm. Remote Sens. 2019, 11, 2393. [CrossRef]

105. Kilpatrick, K.A.; Minnett, P.J.; Luo, B. Validation of NASA MODIS R2019.0 reprocessed SST products. In Proceedings of the 18th International GHRSST Science Team Meeting (GHRSST XVIII), Frascati, Italy, 6-10 June 2019.

106. Jia, C.; Minnett, P.J. High latitude sea surface temperatures derived from MODIS infrared measurements. Remote Sens. Environ. 2020, 251, 112094. [CrossRef]

107. Palmer Station Antarctica. Available online: https://oceaninformatics.ucsd.edu/datazoo/catalogs/pallter/datasets/28 / datatables/28/download (accessed on 12 August 2020). 